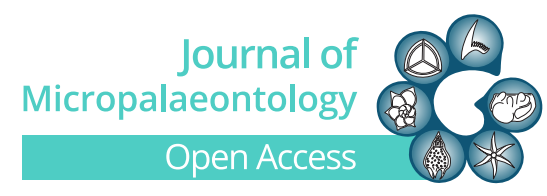

Supplement of

\title{
Reproducibility of species recognition in modern planktonic foraminifera and its implications for analyses of community structure
}

Nadia Al-Sabouni et al.

Correspondence to: Isabel S. Fenton (isabel.fenton@ cantab.net)

The copyright of individual parts of the supplement might differ from the CC BY 4.0 License. 


\section{Section S1: Species list}

The list of the species included in this study. The species list was taken from Hemleben et al. (1989) but has been updated to reflect the current taxonomy, for example Trilobatus rather than Globigerinoides. Two species names (Globorotalia bermudezi and Turborotalita cristata) were used by participants despite not being in the Hemleben et al. (1989) list. Four species from Hemleben were not identified by any of the participants (Gallitellia vivans, Globigerinella adamsi, Globoquadrina conglomerata, Hastigerina digitata). The species used for the transfer function ANN analysis are marked with a '*'.

*Beella digitata (Brady, 1879)

Berggrenia pumilio (Parker, 1962)

Candeina nitida d'Orbigny, 1839

Dentigloborotalia anfracta (Parker, 1967)

Globorotalia bermudezi Rögl \& Bolli, 1973

*Globigerina bulloides d'Orbigny, 1826

* Globigerina falconensis Blow, 1959

* Globigerinella calida (Parker, 1962)

* Globigerinella siphonifera (d'Orbigny, 1839)

* Globigerinita glutinata (Egger, 1893)

Globigerinita minuta (Natland, 1938)

Globigerinita uvula (Ehrenberg, 1861)

* Globigerinoides conglobatus (Brady, 1879)

* Globigerinoides ruber (d'Orbigny, 1839)

*Globigerinoides ruber (pink) (d’Orbigny, 1839) considered a subspecies in Hemleben et al. (1989)

Globorotalia cavernula Bé, 1967

* Globorotalia crassaformis (Galloway \& Wissler, 1927)

*Globorotalia hirsuta (d'Orbigny, 1839)

*Globorotalia inflata (d'Orbigny, 1839)

*Globorotalia menardii (Parker, Jones \& Brady, 1865 after d'Orbigny, 1826 nomen nudum), combined with $G$. tumida for the ANN analysis

*Globorotalia scitula (Brady, 1882)

Globorotalia theyeri Fleisher, 1974

*Globorotalia truncatulinoides (d’Orbigny, 1839)

*Globorotalia tumida (Brady, 1877), combined with G. menardii for the ANN analysis

Globorotalia ungulata Bermúdez, 1961

Globorotaloides hexagonus (Natland, 1938)

*Globoturborotalita rubescens (Hofker, 1956), n.b. in this study this included G. tenella; in the ANN analysis, this was treated as $G$. tenella

*Globoturborotalita rubescens (red) (Hofker, 1956), considered a form of G. rubescens in Hemleben et al. (1989); in the ANN analysis, this was treated as G. rubescens

Hastigerina pelagica (d'Orbigny, 1839)

*Neogloboquadrina dutertrei (d'Orbigny, 1839)

*Neogloboquadrina incompta (Cifelli, 1961) described as N. pachyderma (dex) in Hemleben et al. (1989)

*Neogloboquadrina pachyderma described as N. pachyderma (sin) in Hemleben et al. (1989) (Ehrenberg, 1862)

* Orbulina universa d'Orbigny, 1839

Orcadia riedeli (Rögl \& Bolli, 1973)

*Pulleniatina obliquiloculata (Parker \& Jones, 1865)

*Sphaeroidinella dehiscens (Parker \& Jones, 1865)

Tenuitella fleisheri $\mathrm{Li}, 1987$

Tenuitella iota (Parker, 1962)

Tenuitella parkerae (Brönnimann \& Resig, 1971)

*Trilobatus sacculifer (Brady, 1877)

*Trilobatus trilobus (Brady, 1877), considered a subspecies of T. sacculifer in Hemleben et al. (1989)

Turborotalita clarkei (Rögl \& Bolli, 1973)

Turborotalita cristata (Heron-Allen \& Earland, 1929)

Turborotalita humilis (Brady, 1884)

*Turborotalita quinqueloba (Natland, 1938) 
Section S2: Figures

\section{Slide analysis}

\section{Country}

S1: Germany

S2: Japan

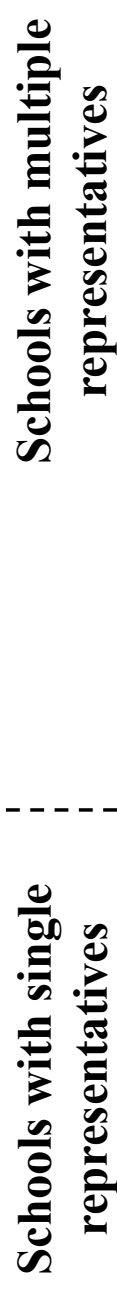

S3: Germany

\section{Teacher $\quad 1^{\text {st }}$ gen $\quad 2^{\text {nd }}$ gen}

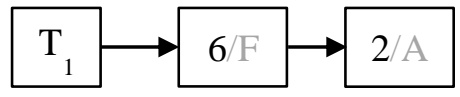

S4: U.K.

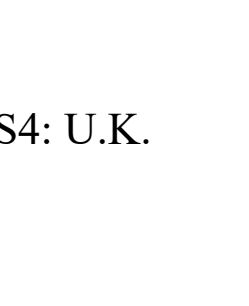

S5: Germany
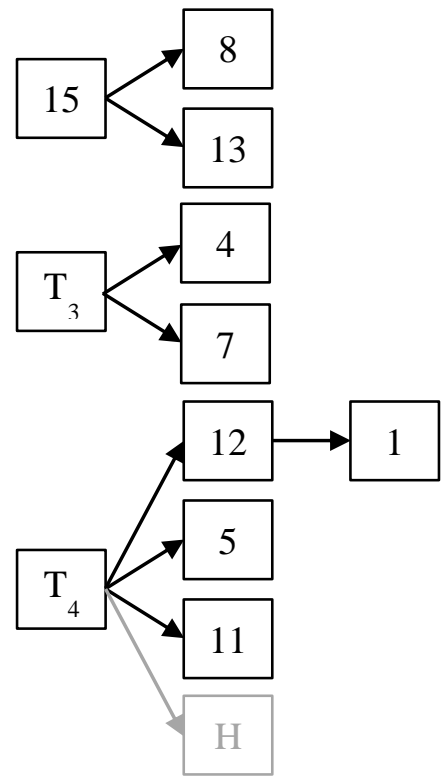

(S6): U.K.

(S7): Netherlands

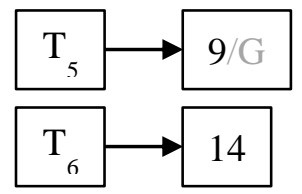

(S8): Portugal

(S9): France

(S10): Italy

\section{Digital analysis}

Teacher $\quad 1^{\text {st }}$ gen $\quad 2^{\text {nd }}$ gen

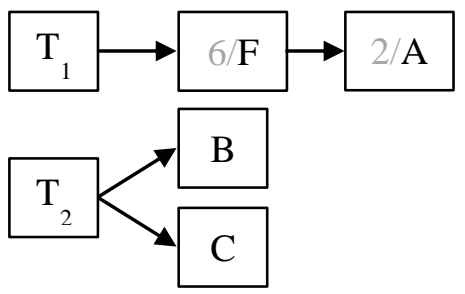

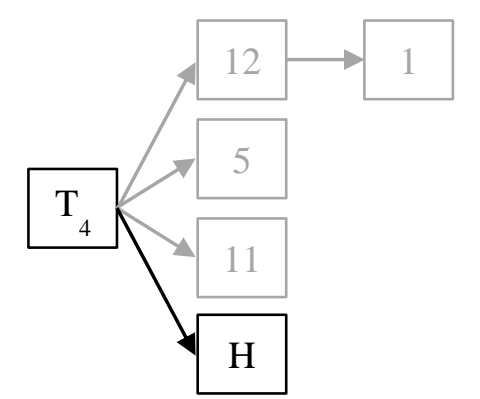
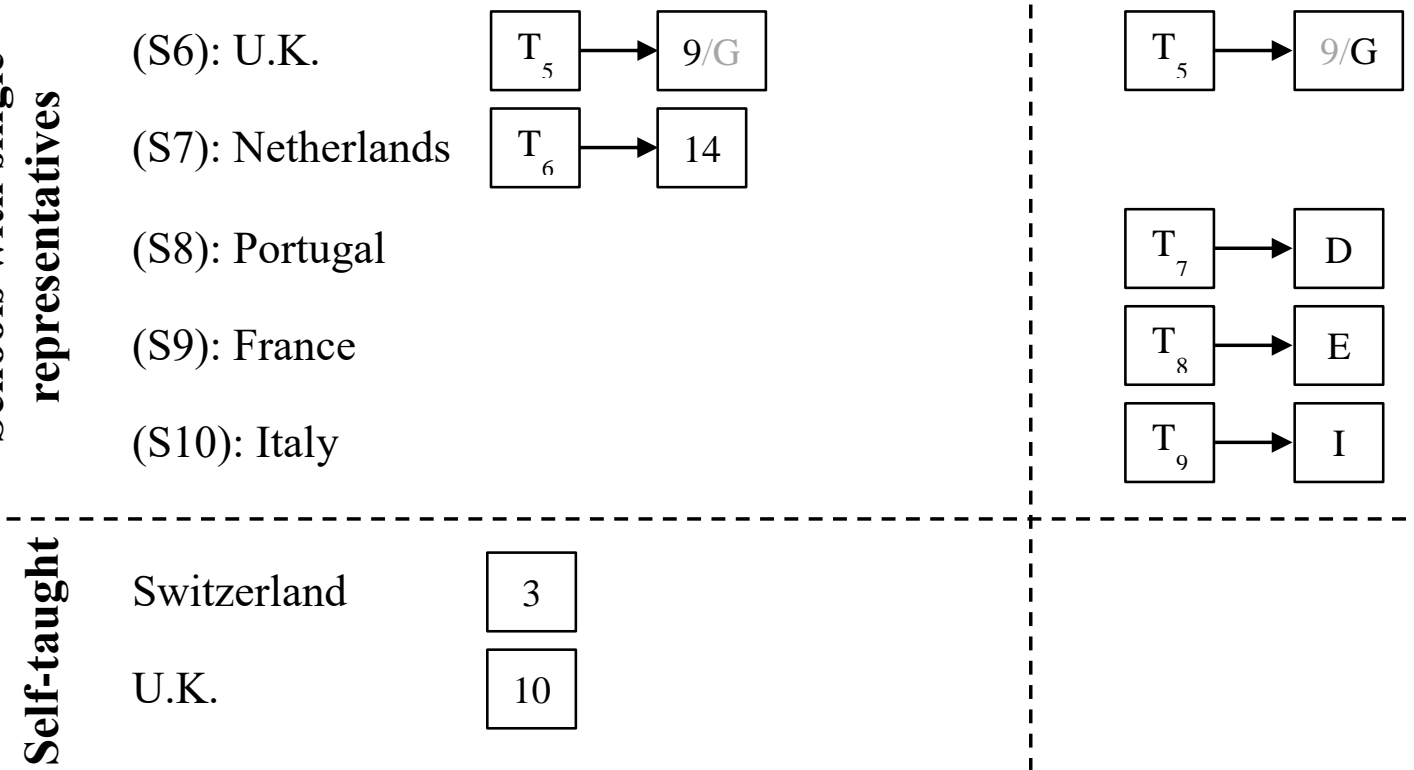

Figure S1: The structure of the taxonomic schools used in this analysis. Schools are relatively stand-alone entities, with little overlap of taxonomic teaching. Some schools (S1-S5; those which are numbered in Table 1) have multiple representatives in this analysis; others (labelled '-' in Table 1) have only a single representative. A few individuals are self-taught. The country gives the dominant location of the representatives of that school at the time of the analysis. In most cases, the original teacher has not been involved in this analysis (T1-T9). However 15 is self-taught, but has Paught other representatives, so is classified as a teacher. 
Full $>125 \mu \mathrm{m}$

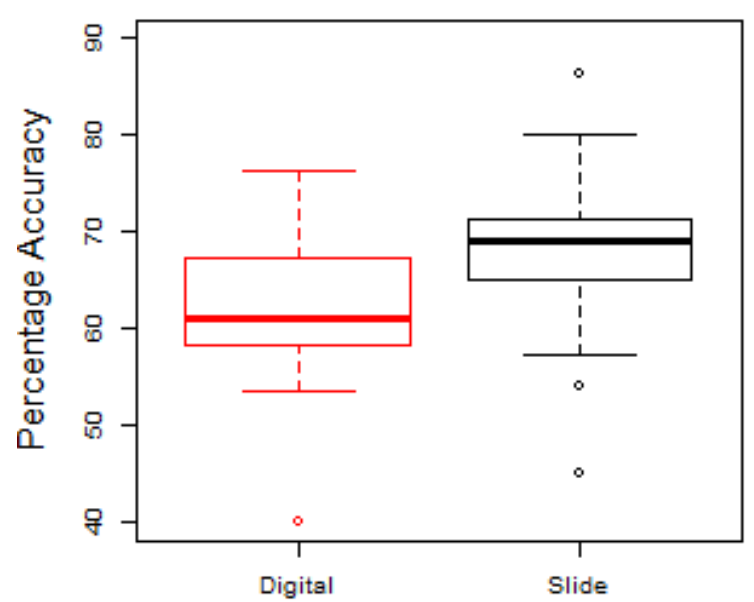

Full $>150 \mu \mathrm{m}$

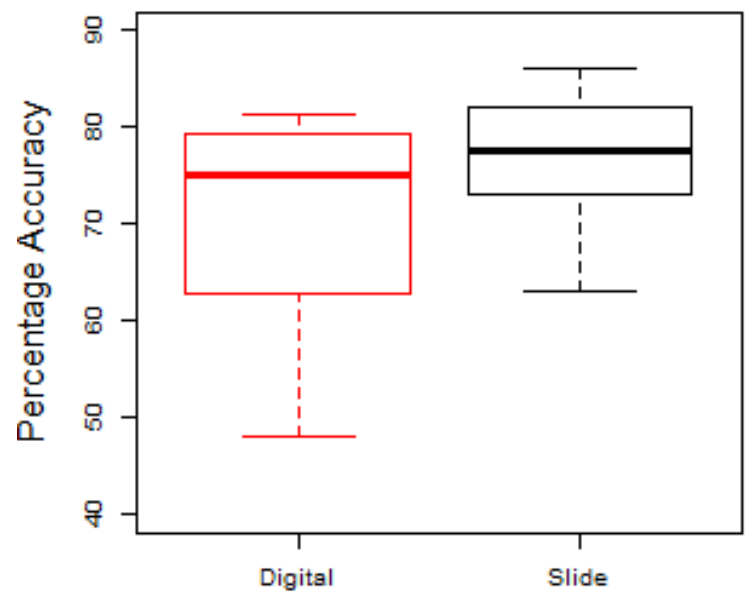

Subsampled $>125 \mu \mathrm{m}$

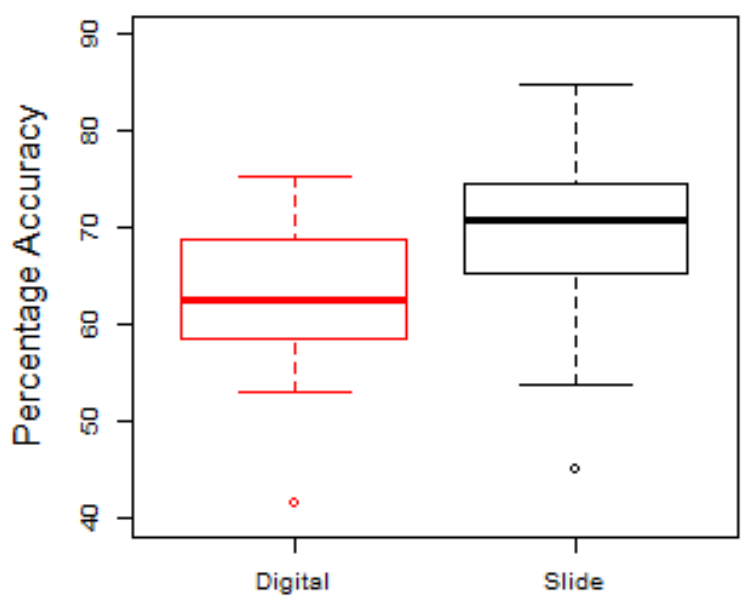

Subsampled $>125 \mu \mathrm{m}$

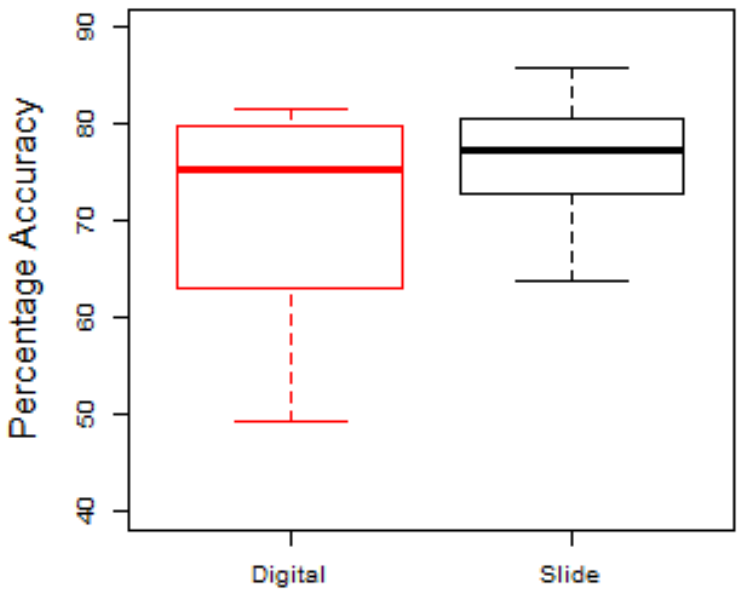

Figure S2: The influence of the number of participants on the percentage accuracy of the slide and digital analyses. The left column shows the full analysis. The right column shows the subsampled results of the recalculated consensus estimates based on equal numbers of slide and digital participants. 

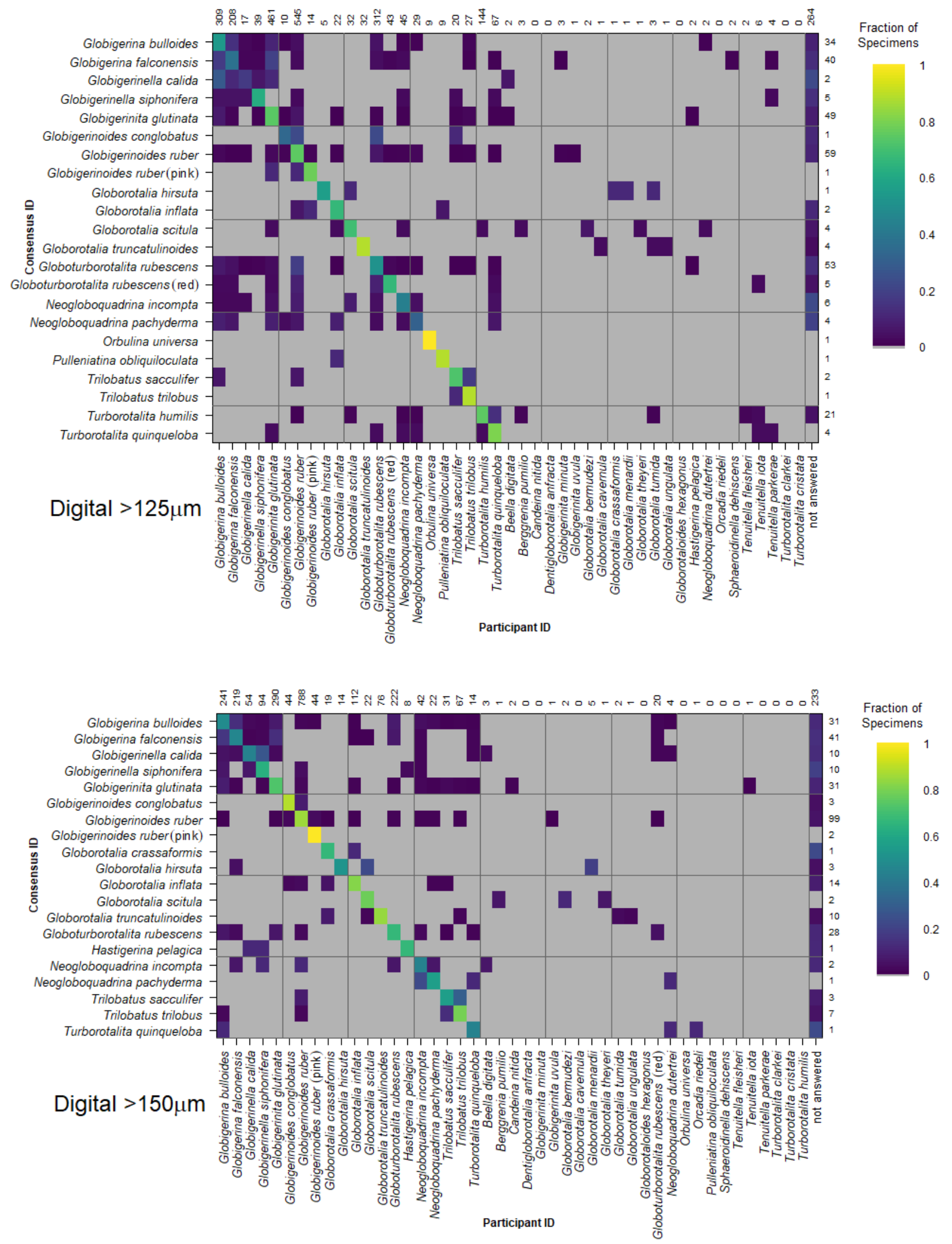

Figure S3: Confusion matrices for taxonomic identifications in the two digital analyses. The $y$-axis shows the consensus ID, and the $x$-axis shows the names given by the participants to the individual specimens. Where a specimen was always identified correctly, only one square in that row would be filled, indicating a fraction of 1 . The numbers along the top indicate the number of specimens given that name in the analysis. The numbers at the right indicate the number of specimens of each species in the consensus ID. Numerical versions of these confusion matrices are available in the supplementary dataset. 


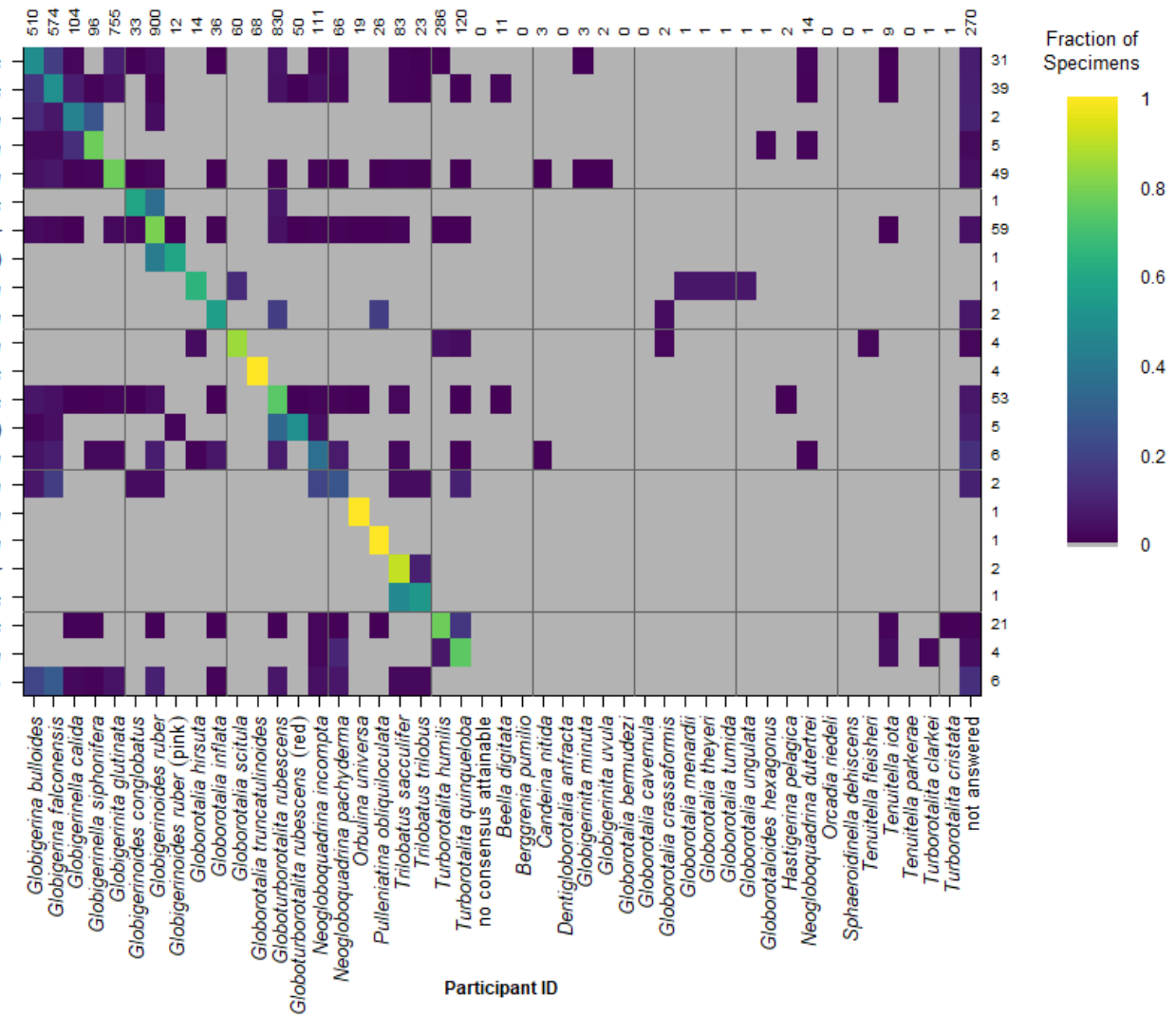

b)

Slide $>125 \mu \mathrm{m}$

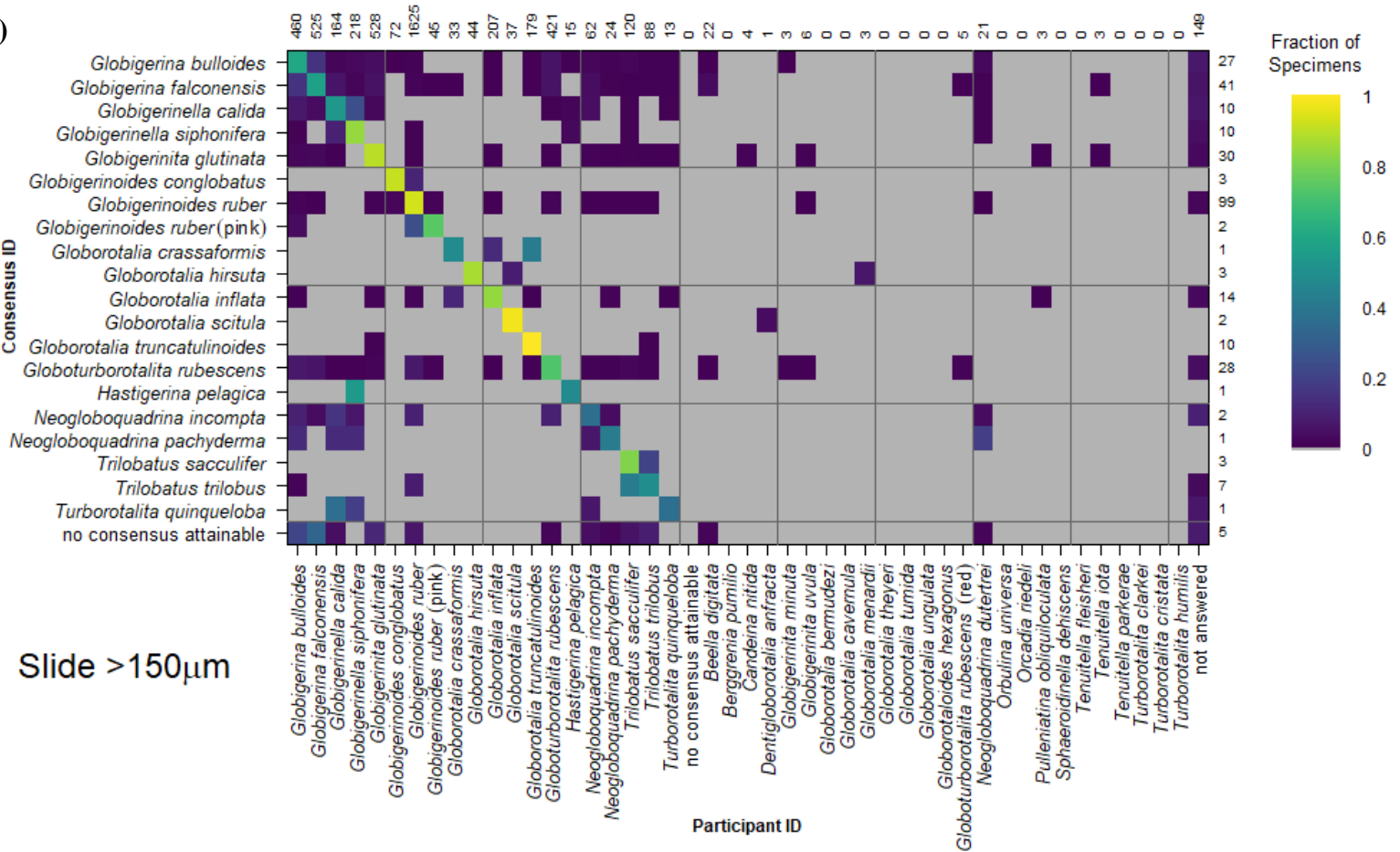

Figure S4: Sensitivity analysis of the method used to split ties in the consensus ID. (a/b) for the slide analysis, (c/d) for the digital analysis. In these confusion matrices ties were classified as "no consensus attainable". The y-axis shows the consensus ID, and the $x$-axis shows the names given by the participants to the individual specimens. Where a specimen was always identified correctly, only one square in that row would be filled, indicating a fraction of 1 . The numbers along the top indicate the number of specimens given that name in the analysis. The numbers at the right indicate the number of specimens of each species in the consensus ID. Numerical versions of these confusion matrices are available in the supplementary dataset. 
c)

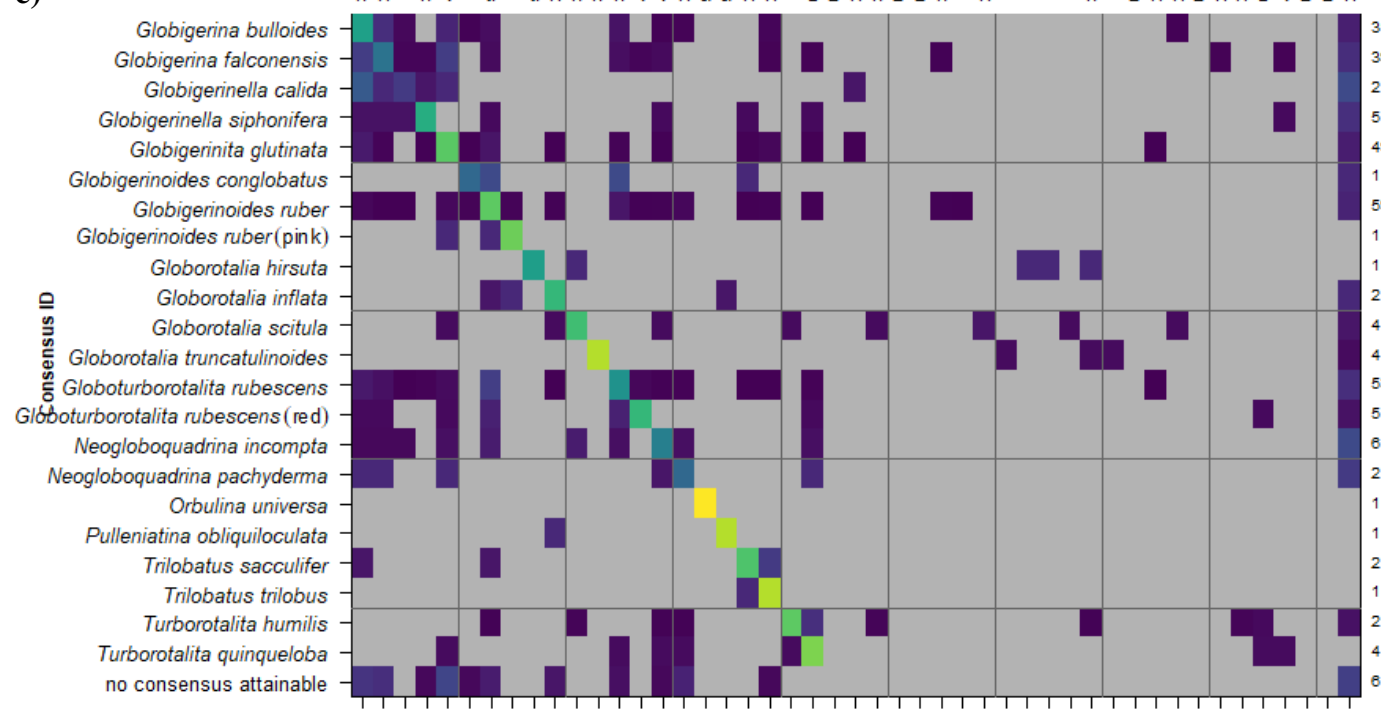

Fraction of

Specimens

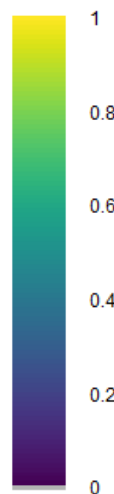

Digital $>125 \mu \mathrm{m}$

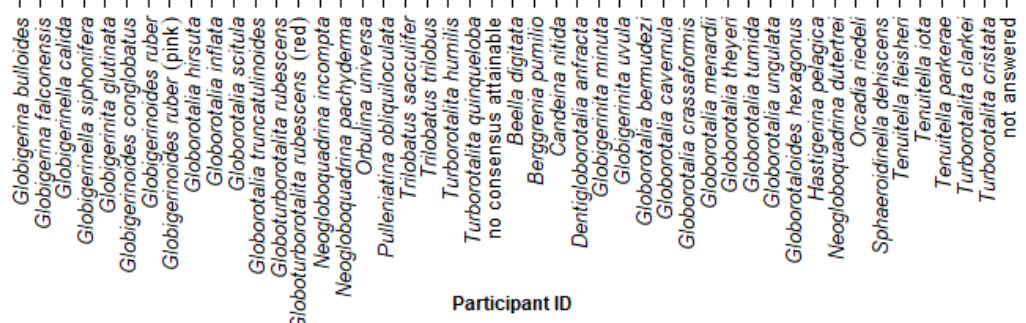

d)

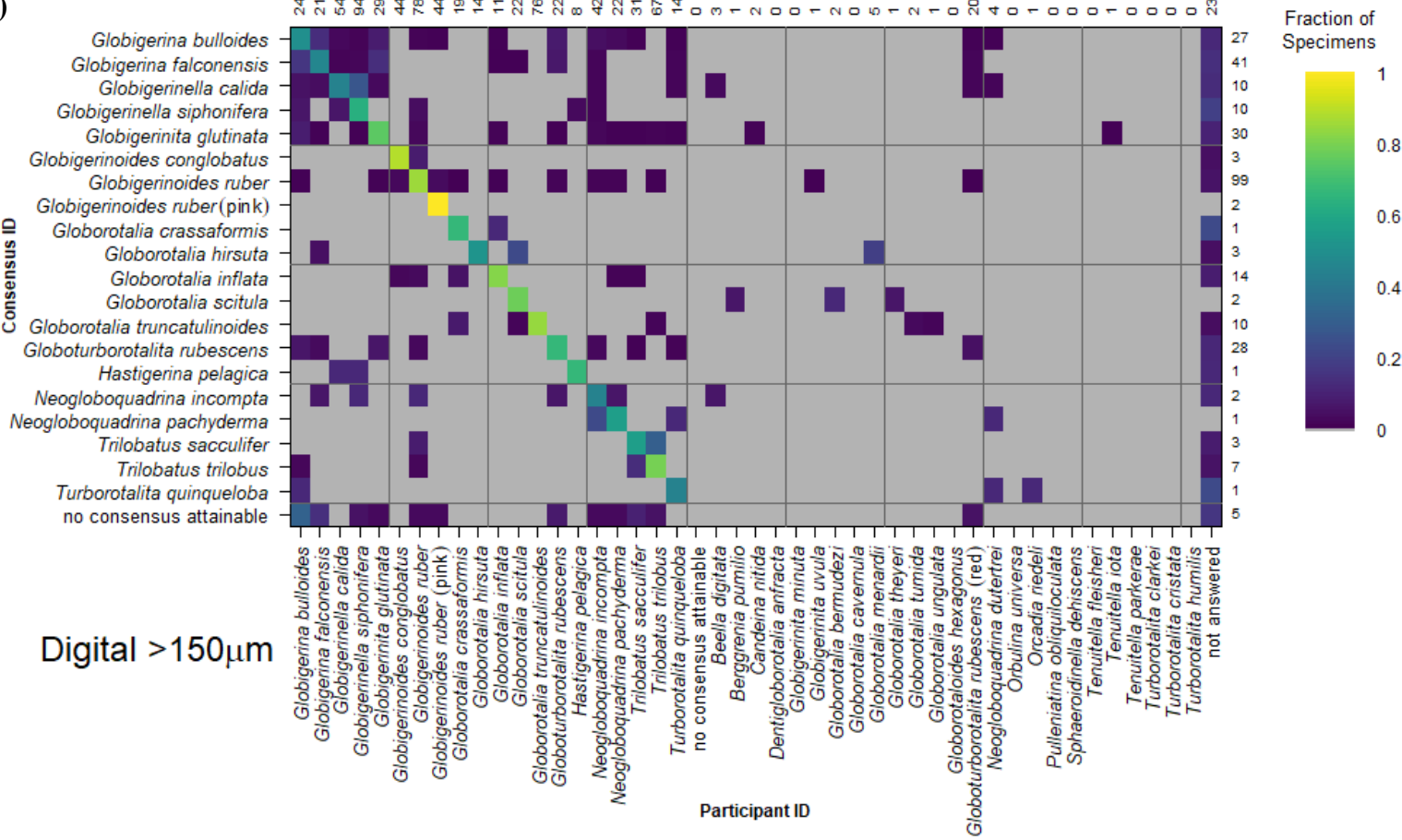

Figure S4 cont. 


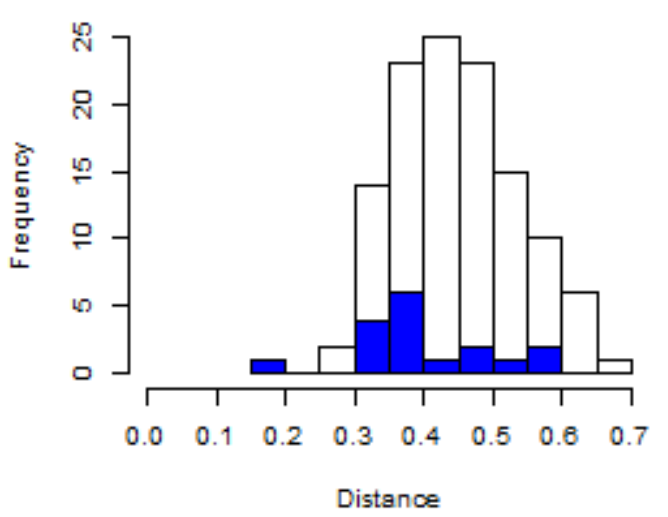

Digital $>125 \mu \mathrm{m}$

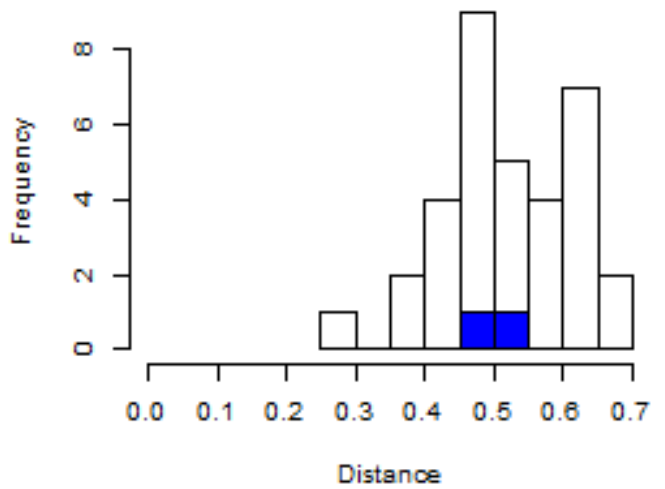

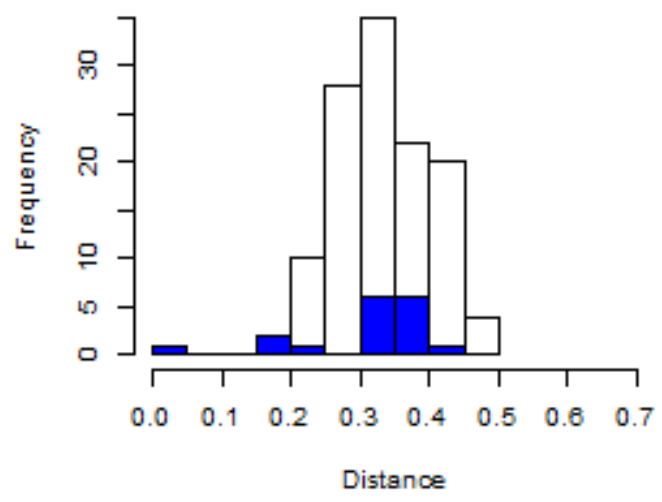

Digital $>150 \mu \mathrm{m}$

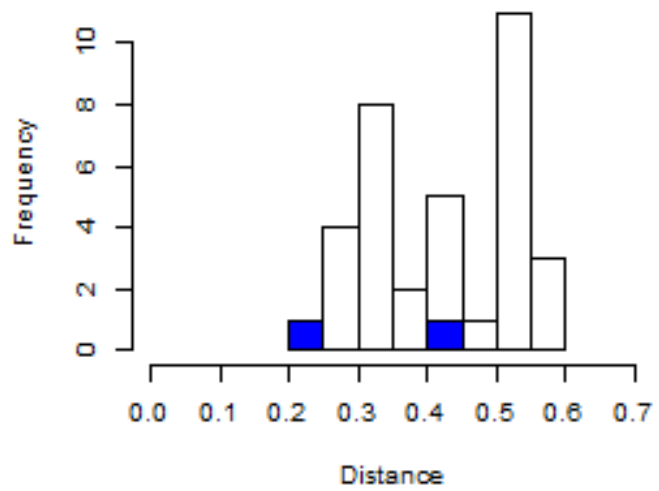

Figure S5: The distances in NMDS space between pairs of points, split by size fraction and slide / digital analyses. Blue bars indicate distances between points within the same school, whilst white bars show the distances for all points not within the same school. 


\section{$>125 \mu \mathrm{m}$}

(a) The transfer function temperature reconstructions are calibrated based on the abundances of the $>150 \mu \mathrm{m}$ size fraction. Therefore they were not calculated for the $>125 \mu \mathrm{m}$ size fraction.

(c)

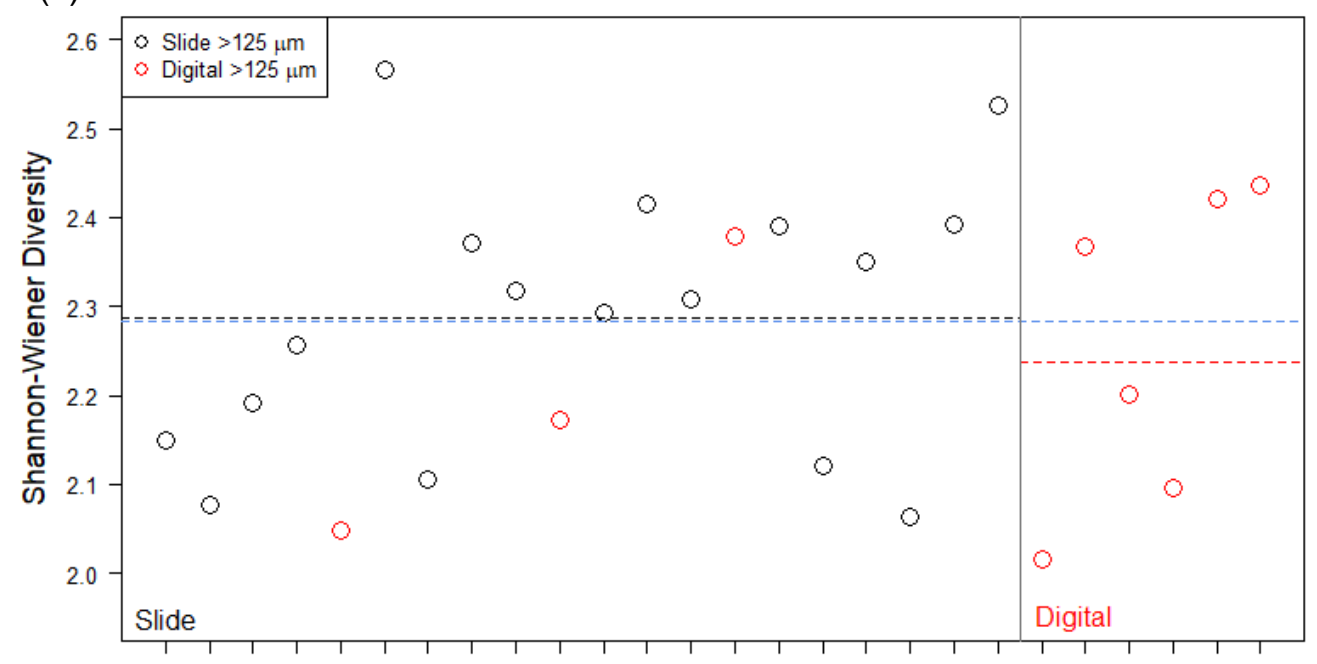

Participant

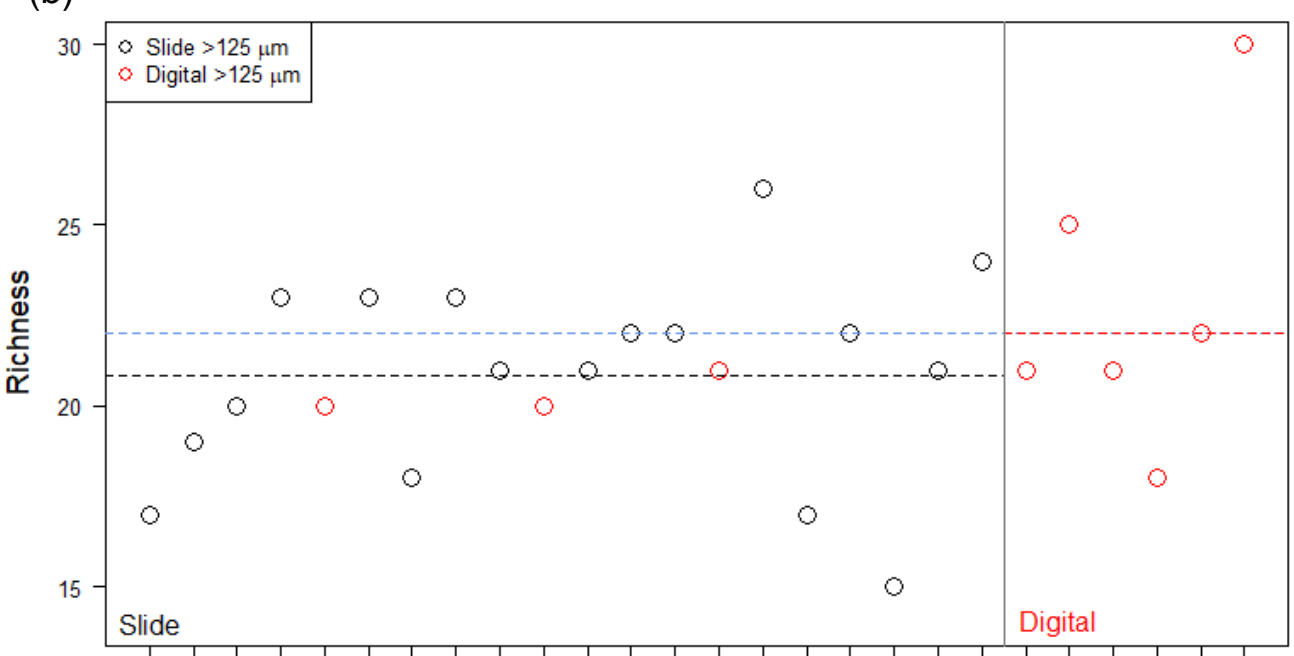

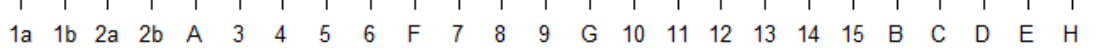

(d)

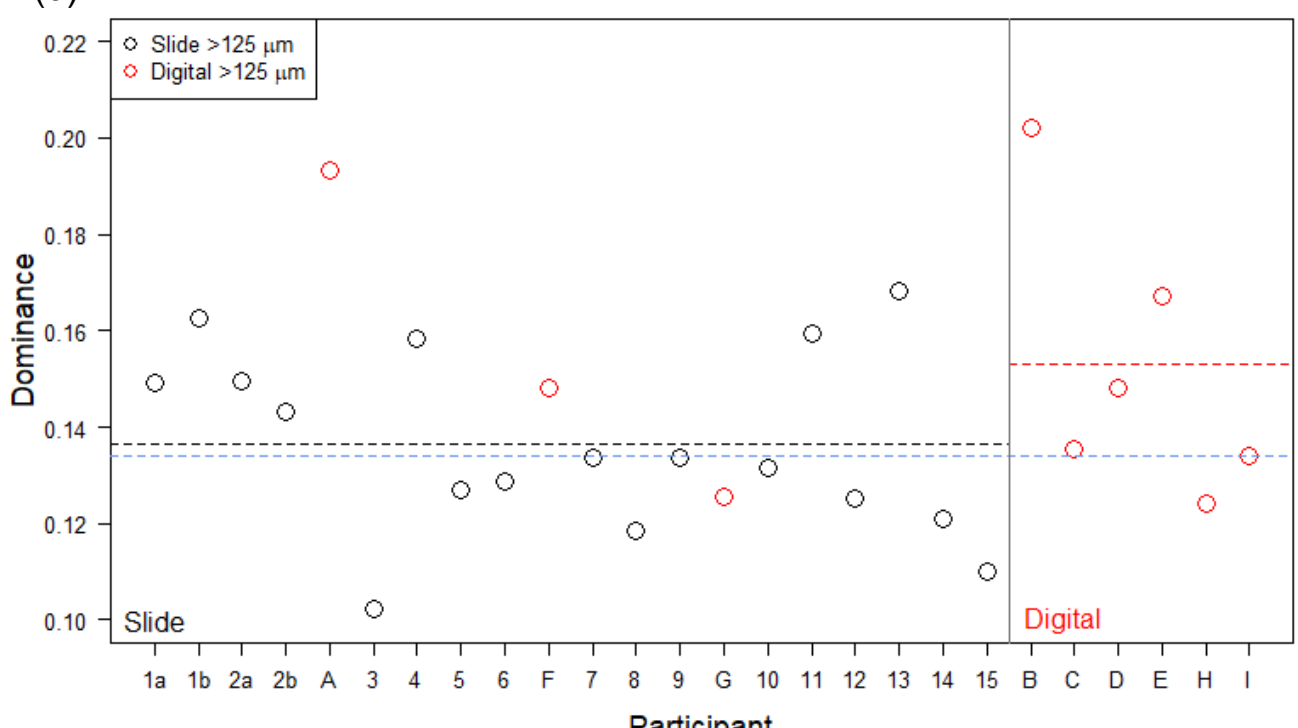

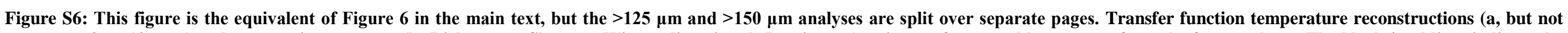

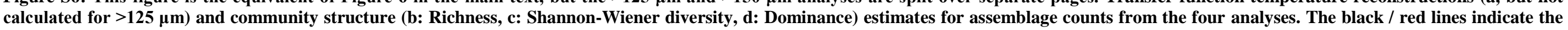

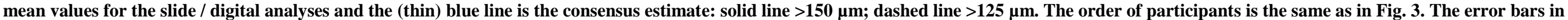

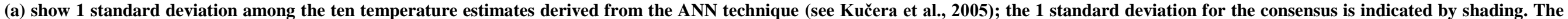
World Ocean Atlas value (thick blue line) is added for reference. 


\section{$>150 \mu \mathrm{m}$}

(a)

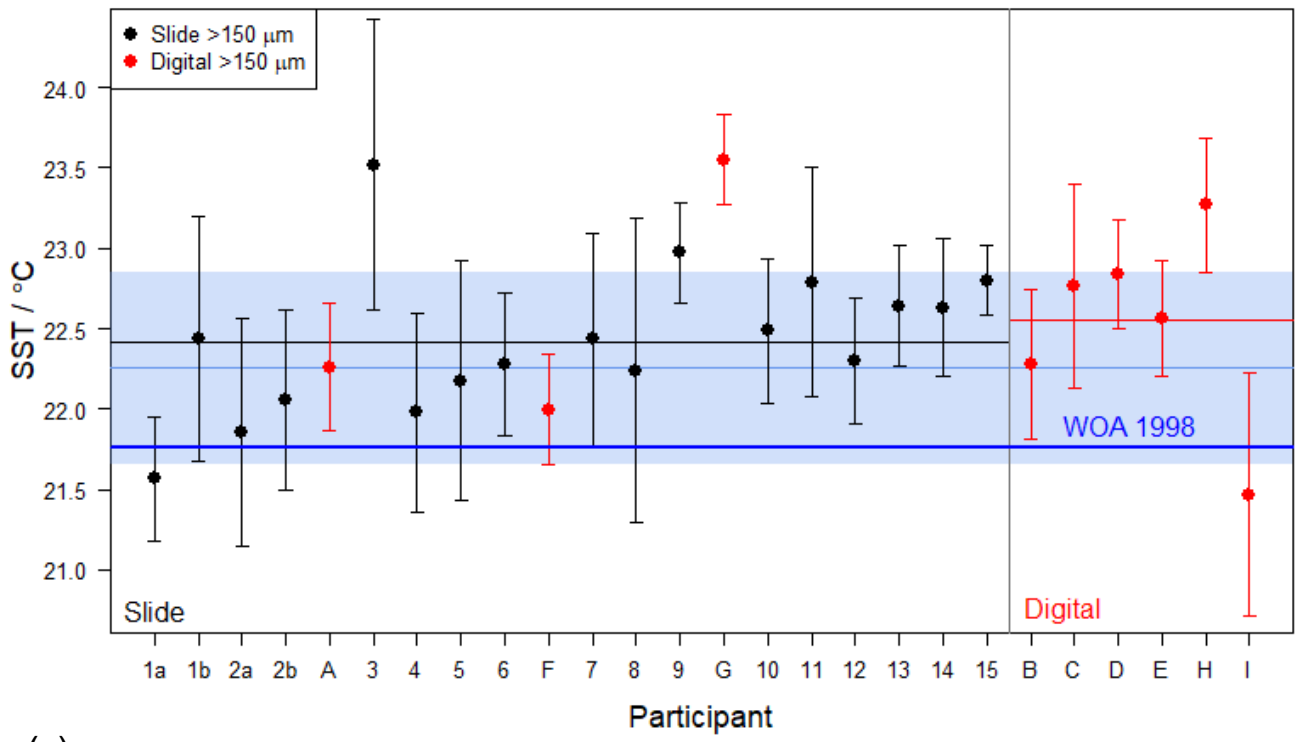

(c)

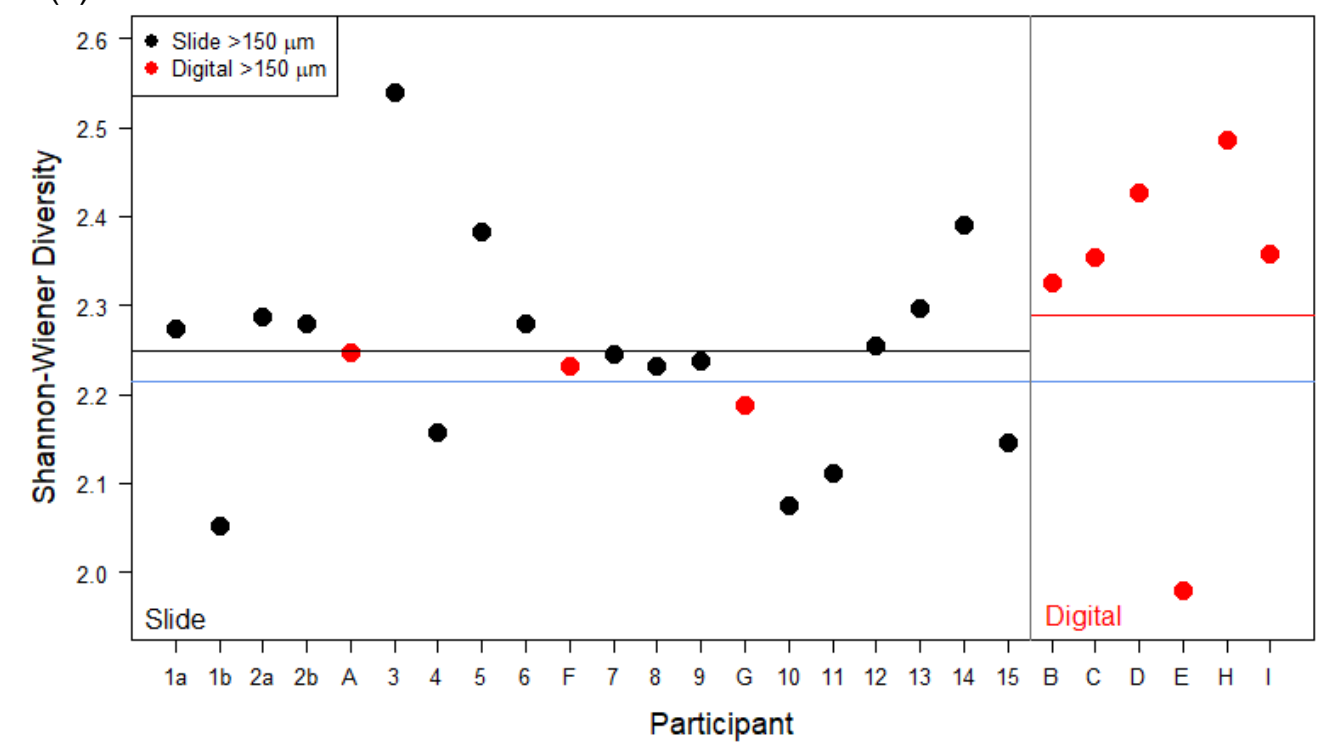

(b)

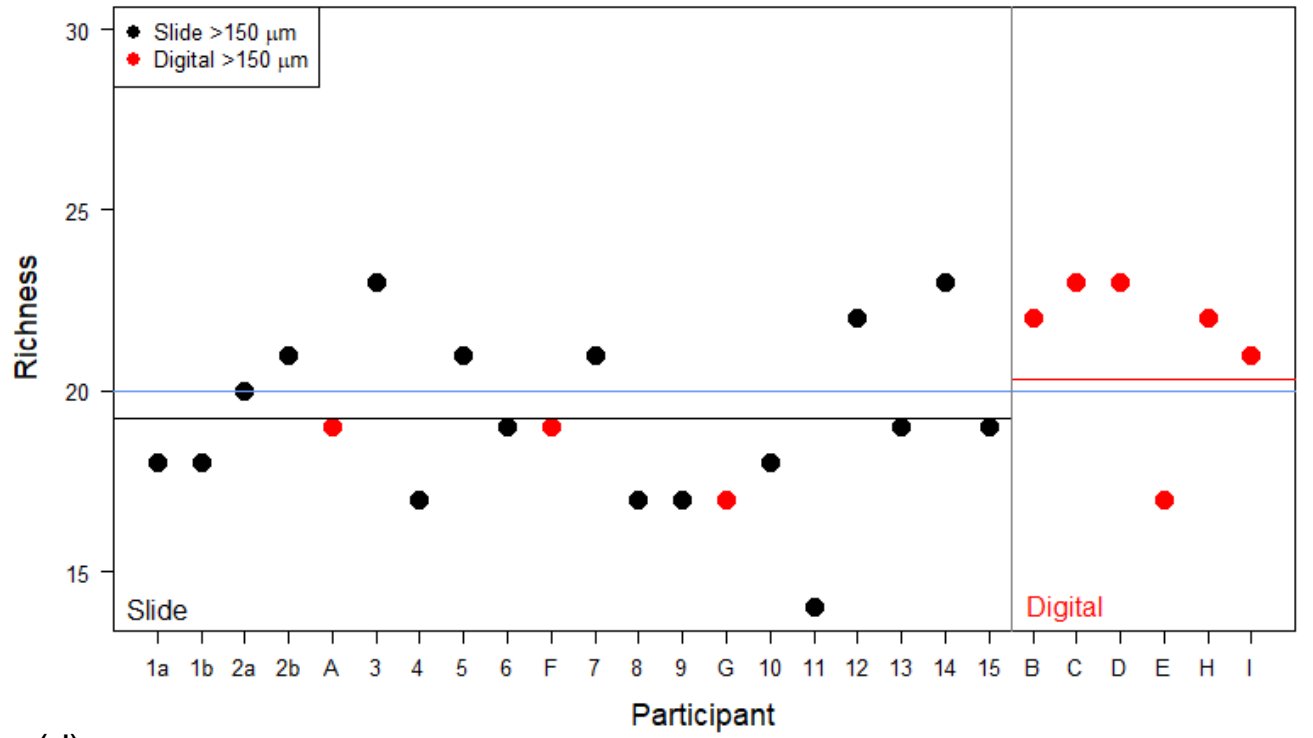

(d)

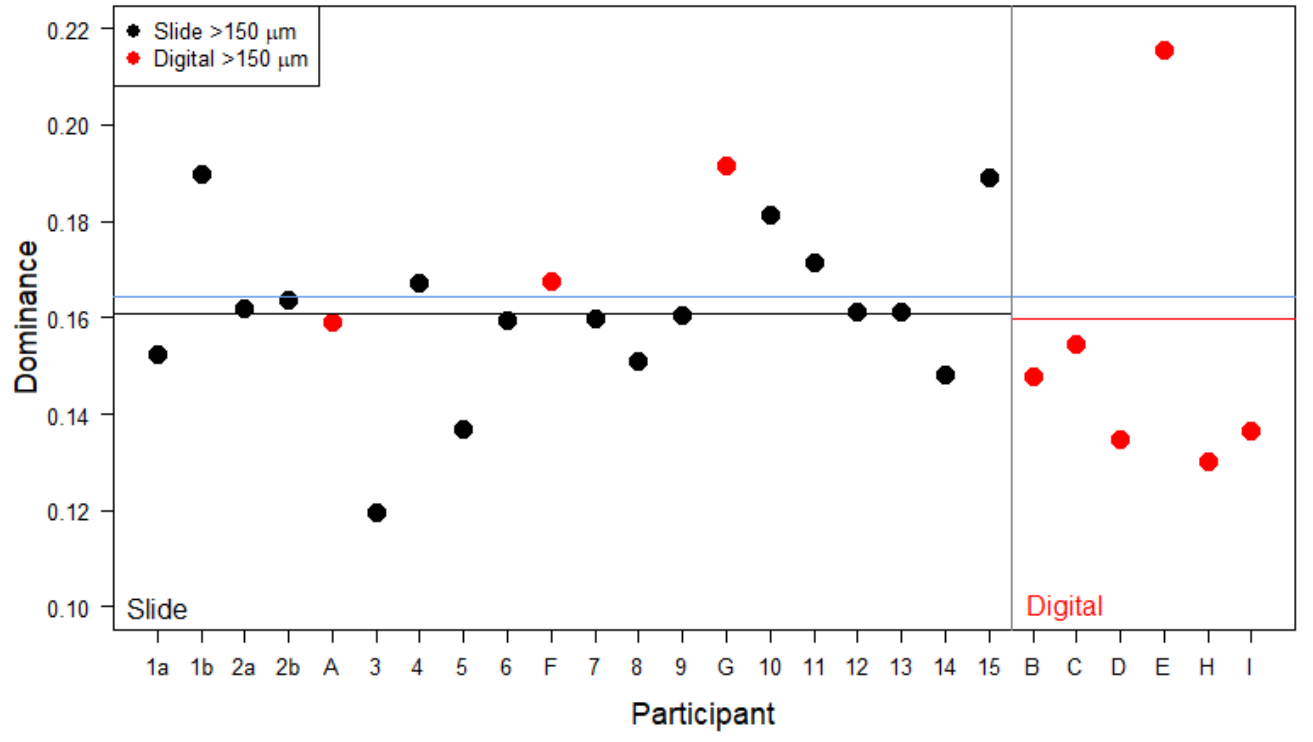

Figure S6 cont. 
Full $>125 \mu \mathrm{m}$

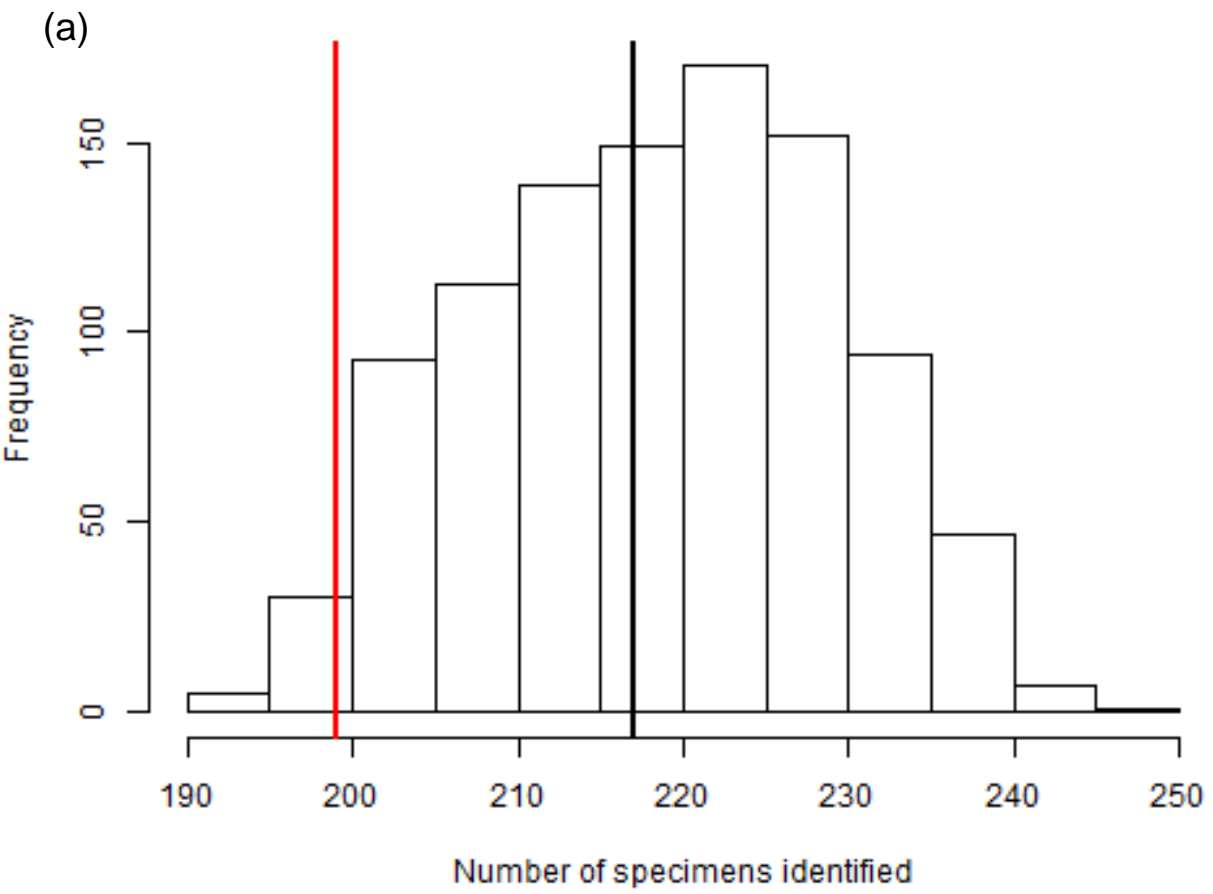

Full $>150 \mu \mathrm{m}$

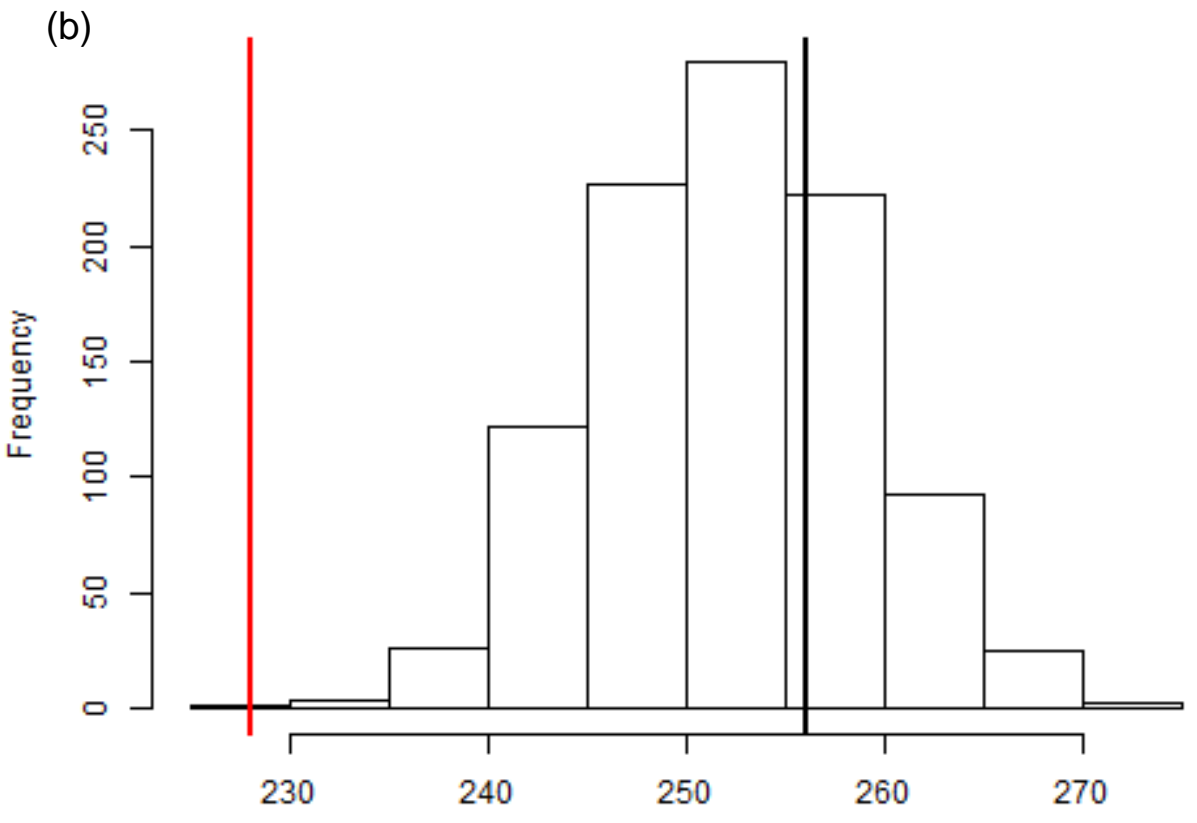

Number of specimens identified

Figure S7: Sensitivity analysis for testing the influence of the number of participants on the levels of agreement in the slide vs. digital separate consensus analyses. These graphs show how the number of specimens identified by the strict consensus (i.e. not classified as "no consensus") varies between the slide and the digital analyses when the consensus values are obtained separately for these analyses. The black line indicates the number of specimens identified in the full slide analysis; the red line indicates the 5 number in the digital analysis. The histogram shows the estimate of the number of specimens for the 1000 replicates of the subsampled slide analysis when the slide data was subsampled to only contain 9 participants. 

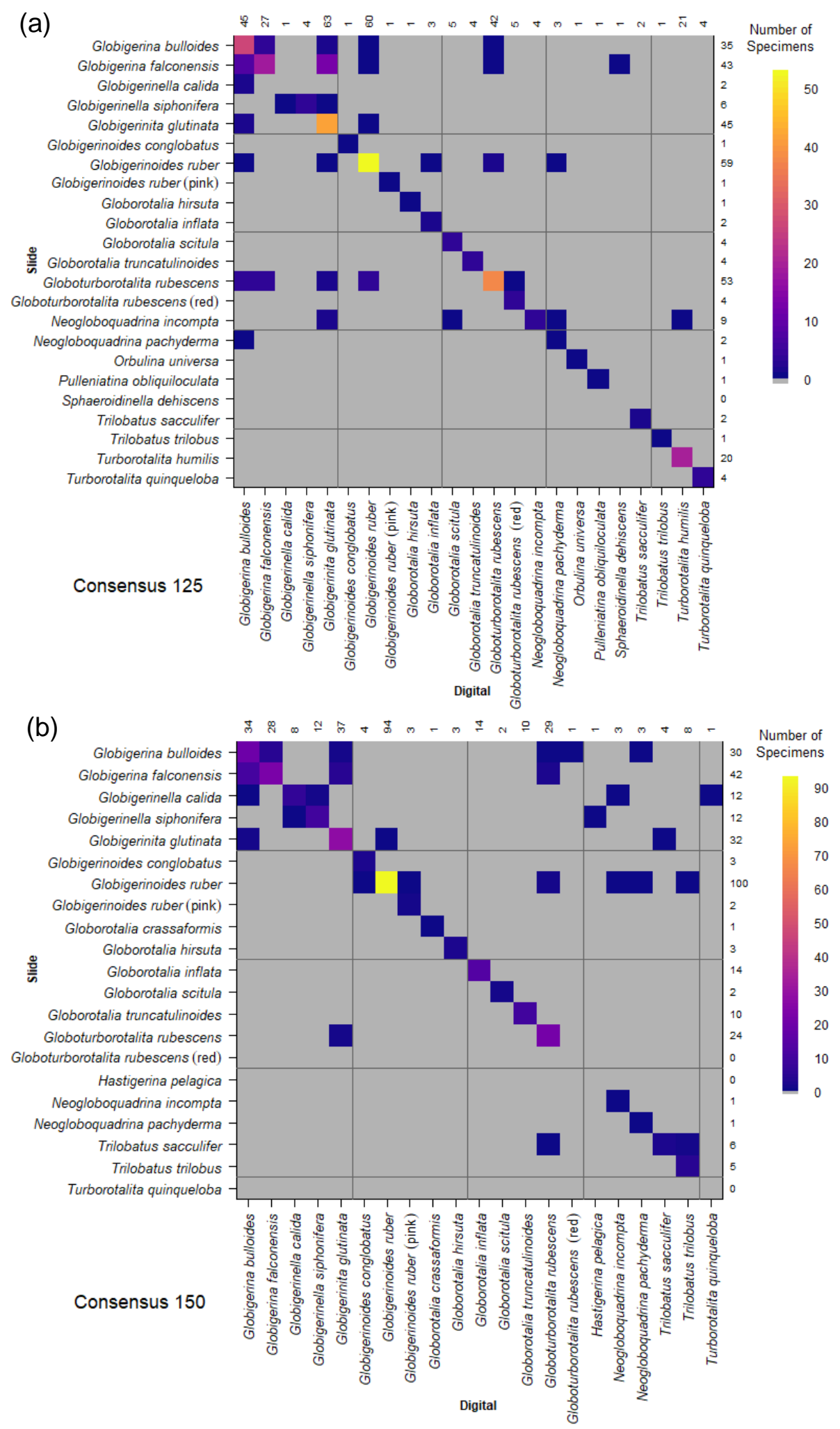

Figure S8: Confusion matrices showing the comparison between the slide and the digital consensus values, if they are calculated separately, for the two size fractions. (a/b) Shows the soft consensus estimates, (c/d) shows the results if ties are designated "no consensus attainable" rather than being split alphabetically. N.b. the colouring on these indicates the number of specimens rather than the fraction correct. The $y$-axis shows the slide consensus ID, and the $x$-axis shows the digital consensus ID. Where both agree on all the specimens of a species, only one square in that row/column would be filled. The values indicate the number of specimens of each species in each consensus ID. Numerical versions of these confusion matrices are available in the supplementary dataset. 
(c)

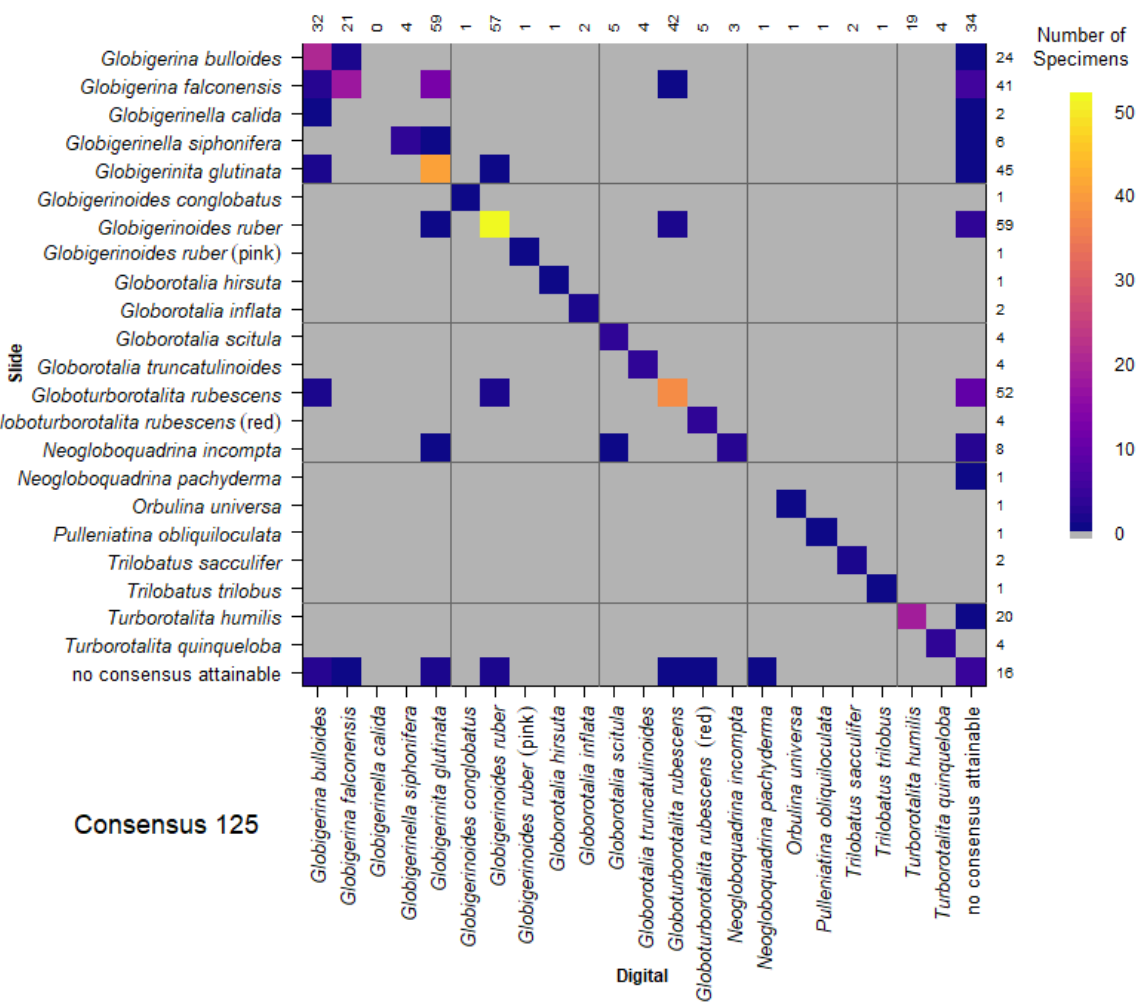

(d)

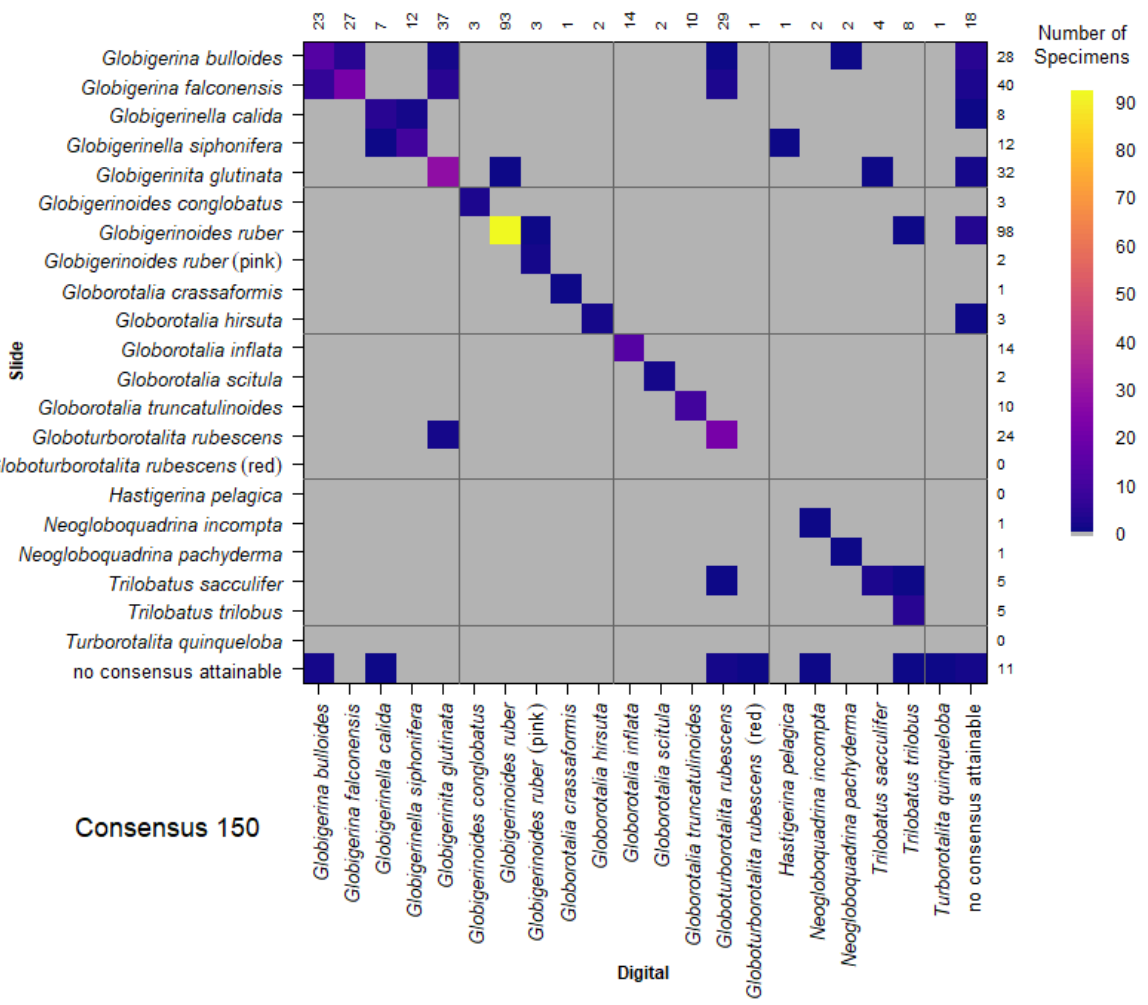




\section{Section S3: Tables}

Table S1: Consistency scores by participant.

\begin{tabular}{|c|c|c|c|c|c|c|c|}
\hline Participant & Analysis & Experience / years & Routine & $\%$ Agreement $>125 \mu \mathrm{m}$ & $\%$ Agreement $>150 \mu \mathrm{m}$ & $\%$ Identified $>125 \mu \mathrm{m}$ & $\%$ Identified $>150 \mu \mathrm{m}$ \\
\hline $1 \mathrm{a}$ & Slide & 0.25 & Yes & 64.00 & 73.67 & 99.67 & 100.00 \\
\hline $1 b$ & Slide & 1 & Yes & 75.67 & 73.00 & 100.00 & 100.00 \\
\hline $2 \mathrm{a}$ & Slide & 2 & Yes & 68.67 & 85.67 & 100.00 & 100.00 \\
\hline $2 b$ & Slide & 3 & Yes & 80.00 & 85.67 & 100.00 & 100.00 \\
\hline 3 & Slide & 6 & No & 57.33 & 63.00 & 100.00 & 100.00 \\
\hline 4 & Slide & 6 & No & 70.67 & 82.67 & 95.67 & 98.33 \\
\hline 5 & Slide & 8 & No & 69.00 & 74.67 & 100.00 & 100.00 \\
\hline 6 & Slide & 11 & No & 70.67 & 82.00 & 100.00 & 100.00 \\
\hline 7 & Slide & 12 & Yes & 79.33 & 86.00 & 100.00 & 100.00 \\
\hline 8 & Slide & 12 & No & 71.33 & 79.33 & 100.00 & 100.00 \\
\hline 9 & Slide & 14 & Yes & 70.67 & 72.00 & 79.33 & 81.67 \\
\hline 10 & Slide & 14 & No & 65.67 & 77.67 & 100.00 & 100.00 \\
\hline 11 & Slide & 17 & No & 65.00 & 75.67 & 100.00 & 100.00 \\
\hline 12 & Slide & 18 & Yes & 86.33 & 79.67 & 100.00 & 100.00 \\
\hline 13 & Slide & 20 & Yes & 45.00 & 65.33 & 48.00 & 76.00 \\
\hline 14 & Slide & 22 & Yes & 67.67 & 79.67 & 93.33 & 98.33 \\
\hline 15 & Slide & 39 & No & 54.00 & 69.33 & 94.00 & 96.00 \\
\hline A & Digital & 3 & Yes & 58.33 & 80.33 & 100.00 & 100.00 \\
\hline B & Digital & 3 & Yes & 58.33 & 79.33 & 100.00 & 99.67 \\
\hline $\mathrm{C}$ & Digital & 6 & Yes & 61.00 & 62.67 & 100.00 & 100.00 \\
\hline $\mathrm{D}$ & Digital & 6 & Yes & 70.67 & 77.67 & 93.33 & 99.33 \\
\hline E & Digital & 7 & Yes & 40.00 & 48.00 & 65.67 & 70.33 \\
\hline $\mathrm{F}$ & Digital & 12 & No & 76.33 & 81.33 & 100.00 & 100.00 \\
\hline $\mathrm{G}$ & Digital & 14 & Yes & 53.33 & 49.33 & 59.67 & 56.33 \\
\hline $\mathrm{H}$ & Digital & 16 & Yes & 67.33 & 71.33 & 93.67 & 96.67 \\
\hline I & Digital & 18 & Yes & 67.33 & 75.00 & 99.67 & 100.00 \\
\hline
\end{tabular}


Table S2: The diversity metrics and sea surface temperature estimates for each of the participants and the consensus estimates.

\begin{tabular}{|c|c|c|c|c|c|c|c|c|c|}
\hline \multirow[t]{2}{*}{ Participant } & \multirow{2}{*}{ Analysis } & \multicolumn{2}{|c|}{ Richness } & \multicolumn{2}{|c|}{ Shannon Wiener } & \multicolumn{2}{|c|}{ Dominance } & \multirow[t]{2}{*}{ SST $10 \mathrm{~m} /{ }^{\circ} \mathrm{C}$} & \multirow[t]{2}{*}{ SD SST $/{ }^{\circ} \mathrm{C}$} \\
\hline & & 125 & 150 & 125 & 150 & 125 & 150 & & \\
\hline consensus & - & 22 & 20 & 2.28 & 2.21 & 0.13 & 0.16 & 22.25 & 0.60 \\
\hline $1 \mathrm{a}$ & Slide & 17 & 18 & 2.15 & 2.27 & 0.15 & 0.15 & 21.57 & 0.38 \\
\hline $1 b$ & Slide & 19 & 18 & 2.08 & 2.05 & 0.16 & 0.19 & 22.43 & 0.76 \\
\hline $2 \mathrm{a}$ & Slide & 20 & 20 & 2.19 & 2.29 & 0.15 & 0.16 & 21.85 & 0.71 \\
\hline $2 b$ & Slide & 23 & 21 & 2.26 & 2.28 & 0.14 & 0.16 & 22.06 & 0.56 \\
\hline 3 & Slide & 23 & 23 & 2.57 & 2.54 & 0.10 & 0.12 & 23.52 & 0.91 \\
\hline 4 & Slide & 18 & 17 & 2.10 & 2.16 & 0.16 & 0.17 & 21.98 & 0.62 \\
\hline 5 & Slide & 23 & 21 & 2.37 & 2.38 & 0.13 & 0.14 & 22.17 & 0.75 \\
\hline 6 & Slide & 21 & 19 & 2.32 & 2.28 & 0.13 & 0.16 & 22.28 & 0.44 \\
\hline 7 & Slide & 21 & 21 & 2.29 & 2.24 & 0.13 & 0.16 & 22.43 & 0.66 \\
\hline 8 & Slide & 22 & 17 & 2.42 & 2.23 & 0.12 & 0.15 & 22.24 & 0.94 \\
\hline 9 & Slide & 22 & 17 & 2.31 & 2.24 & 0.13 & 0.16 & 22.97 & 0.31 \\
\hline 10 & Slide & 26 & 18 & 2.39 & 2.08 & 0.13 & 0.18 & 22.48 & 0.45 \\
\hline 11 & Slide & 17 & 14 & 2.12 & 2.11 & 0.16 & 0.17 & 22.79 & 0.71 \\
\hline 12 & Slide & 22 & 22 & 2.35 & 2.25 & 0.13 & 0.16 & 22.30 & 0.40 \\
\hline 13 & Slide & 15 & 19 & 2.06 & 2.30 & 0.17 & 0.16 & 22.64 & 0.38 \\
\hline 14 & Slide & 21 & 23 & 2.39 & 2.39 & 0.12 & 0.15 & 22.63 & 0.43 \\
\hline 15 & Slide & 24 & 19 & 2.53 & 2.14 & 0.11 & 0.19 & 22.80 & 0.21 \\
\hline A & Digital & 20 & 19 & 2.05 & 2.25 & 0.19 & 0.16 & 22.26 & 0.40 \\
\hline B & Digital & 21 & 22 & 2.01 & 2.33 & 0.20 & 0.15 & 22.28 & 0.47 \\
\hline $\mathrm{C}$ & Digital & 25 & 23 & 2.37 & 2.35 & 0.14 & 0.15 & 22.76 & 0.64 \\
\hline $\mathrm{D}$ & Digital & 21 & 23 & 2.20 & 2.43 & 0.15 & 0.13 & 22.84 & 0.34 \\
\hline $\mathrm{E}$ & Digital & 18 & 17 & 2.10 & 1.98 & 0.17 & 0.22 & 22.56 & 0.36 \\
\hline $\mathrm{F}$ & Digital & 20 & 19 & 2.17 & 2.23 & 0.15 & 0.17 & 21.99 & 0.34 \\
\hline $\mathrm{G}$ & Digital & 21 & 17 & 2.38 & 2.19 & 0.13 & 0.19 & 23.55 & 0.28 \\
\hline $\mathrm{H}$ & Digital & 22 & 22 & 2.42 & 2.49 & 0.12 & 0.13 & 23.27 & 0.42 \\
\hline I & Digital & 30 & 21 & 2.44 & 2.36 & 0.13 & 0.14 & 21.47 & 0.76 \\
\hline
\end{tabular}


Table S3: The maximum diameter of species based on the specimens, identified by a strict consensus, in this analysis

\begin{tabular}{l|c}
\hline Species & Max. diameter / $\boldsymbol{\mu m}$ \\
\hline Neogloboquadrina incompta & 164.86 \\
Turborotalita quinqueloba & 185.38 \\
Globoturborotalita rubescens (red) & 191.28 \\
Turborotalita humilis & 239.86 \\
Globorotalia scitula & 248.52 \\
Globoturborotalita rubescens & 259.64 \\
Globigerina falconensis & 333.15 \\
Globigerinita glutinata & 362.70 \\
Globigerinoides ruber (pink) & 382.11 \\
Globigerinoides ruber & 383.6 \\
Globigerina bulloides & 390.54 \\
Pulleniatina obliquiloculata & 437.85 \\
Globigerinella siphonifera & 453.97 \\
Globorotalia inflata & 479.12 \\
Trilobatus trilobus & 494.72 \\
Globorotalia crassaformis & 538.68 \\
Hastigerina pelagica & 561.89 \\
Trilobatus sacculifer & 564.65 \\
Globigerinella calida & 590.02 \\
Globigerinoides conglobatus & 598.76 \\
Orbulina universa & 612.49 \\
Globorotalia hirsuta & 638.76 \\
Globorotalia truncatulinoides & 709.96 \\
\hline &
\end{tabular}




\section{Section S4: Digital examples by species}

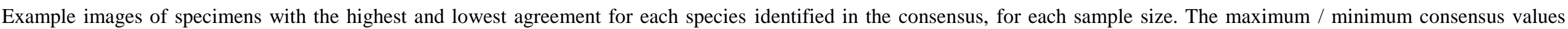
indicate the number of participants (out of 26) who agreed on the identification of that specimen.

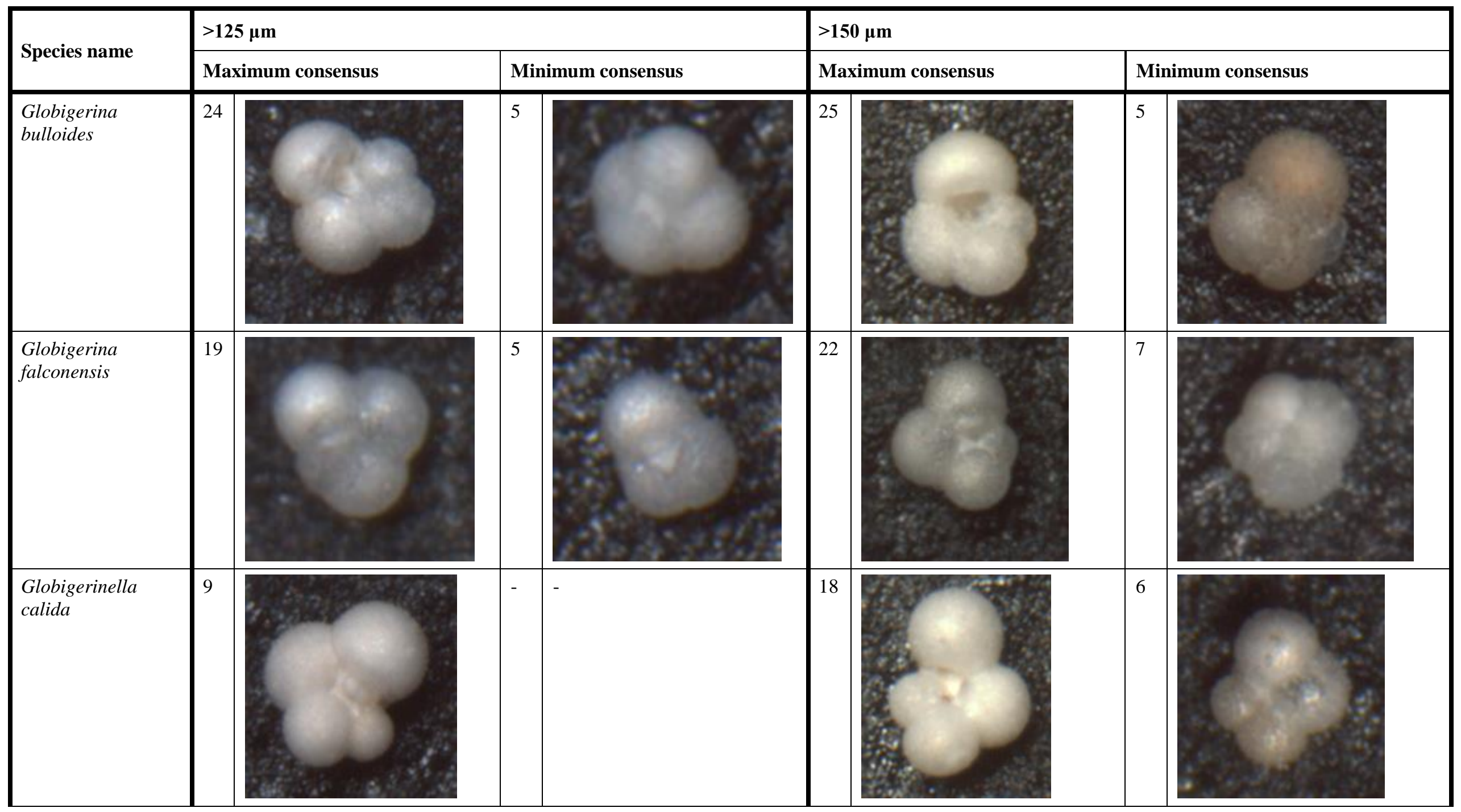




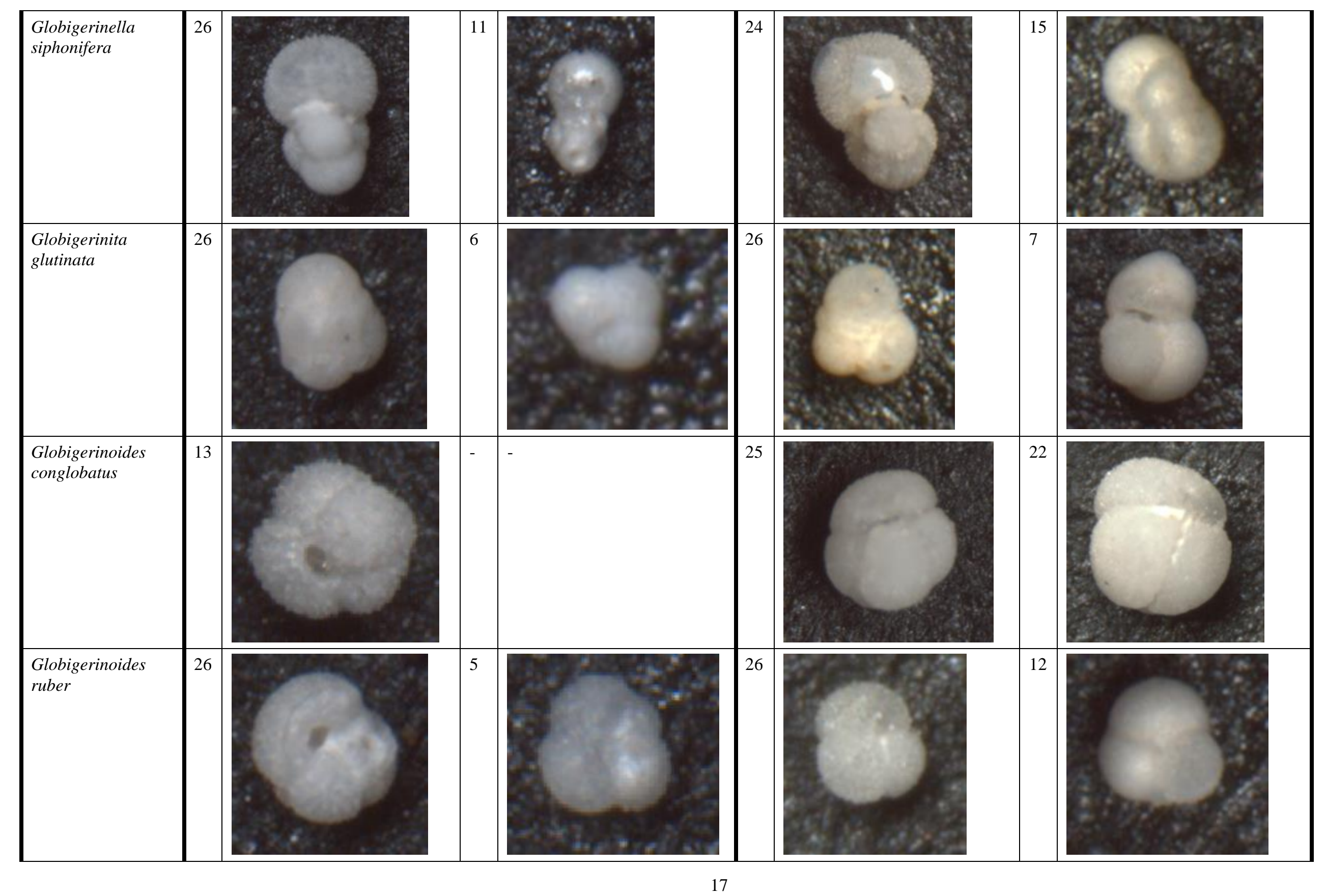




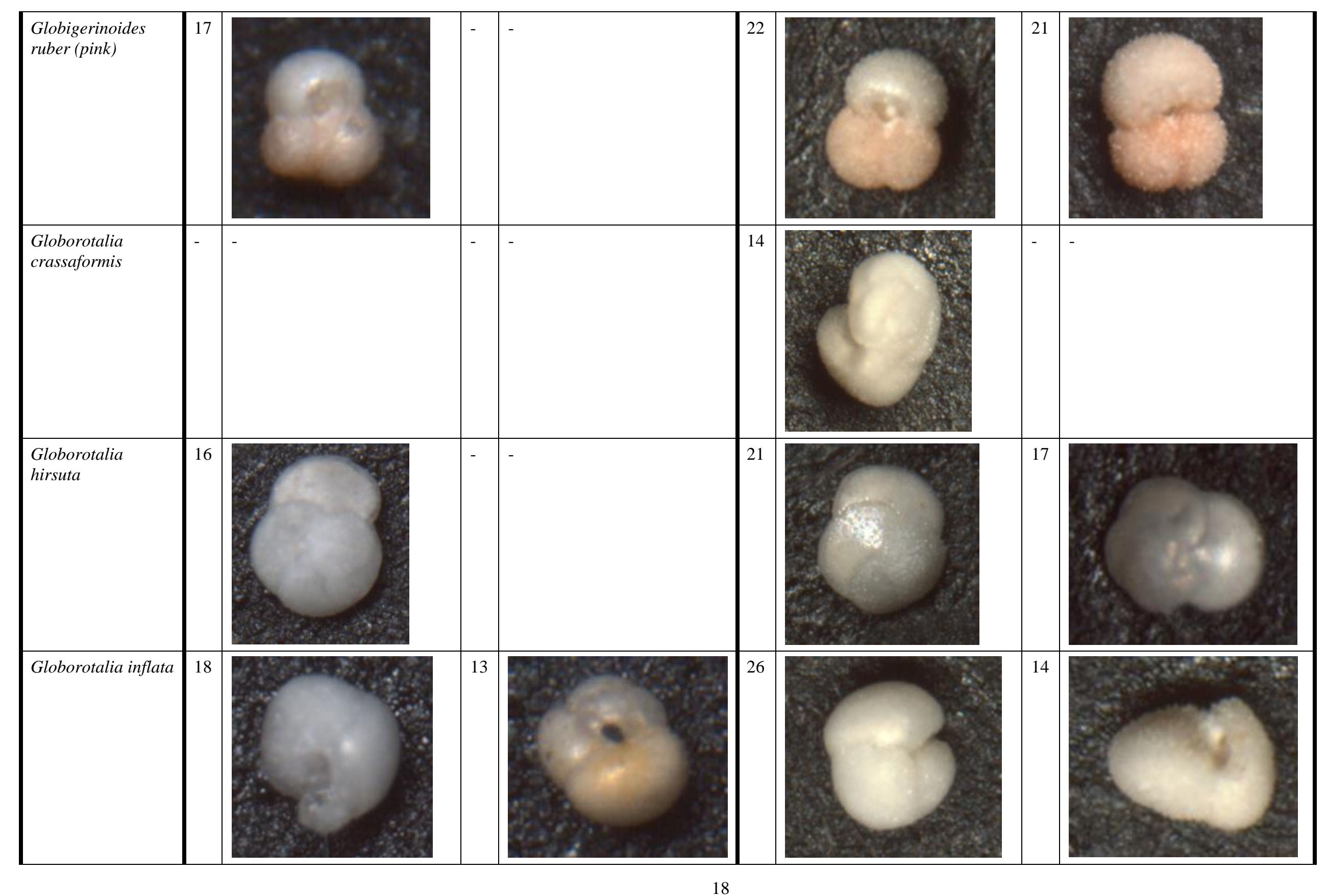




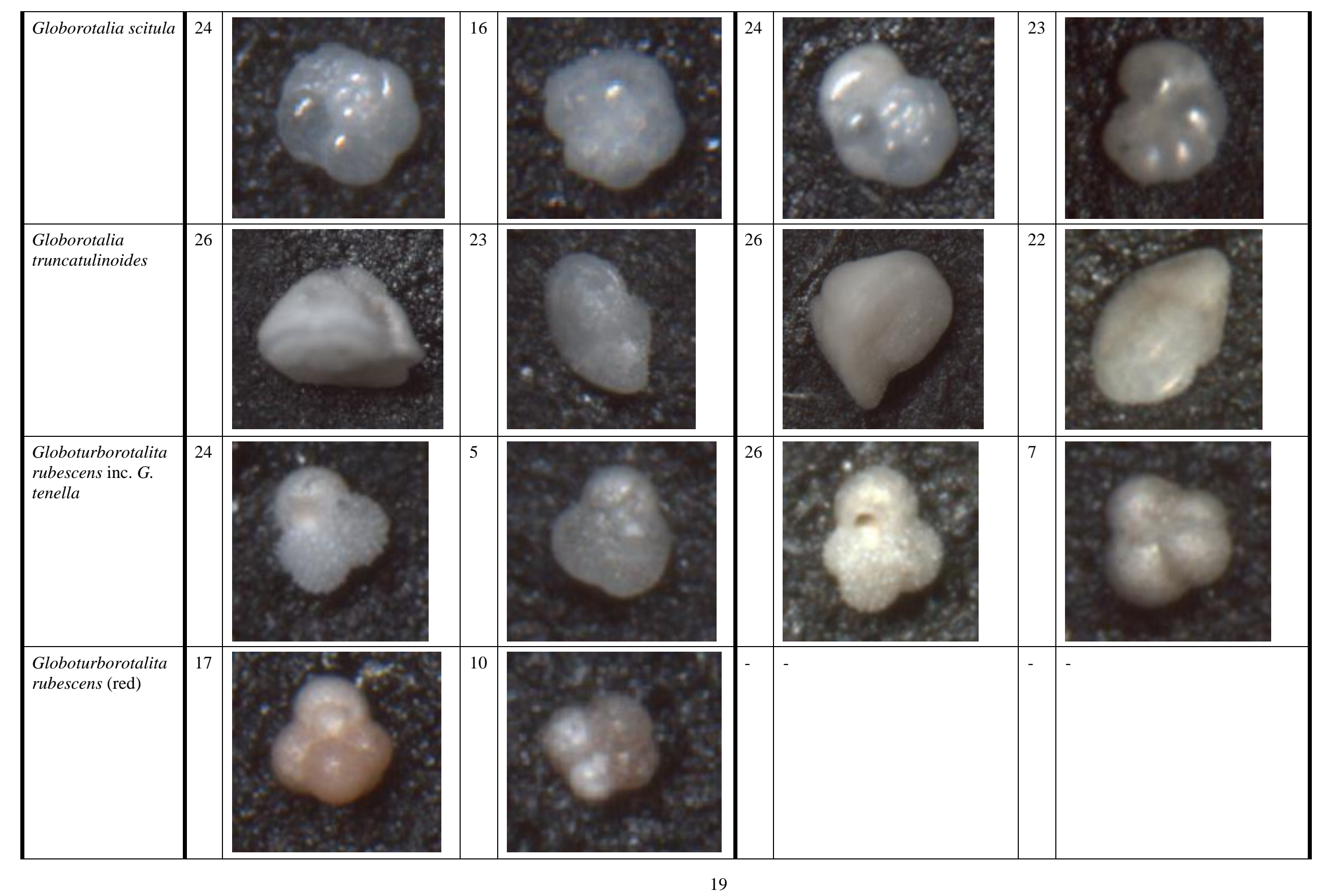




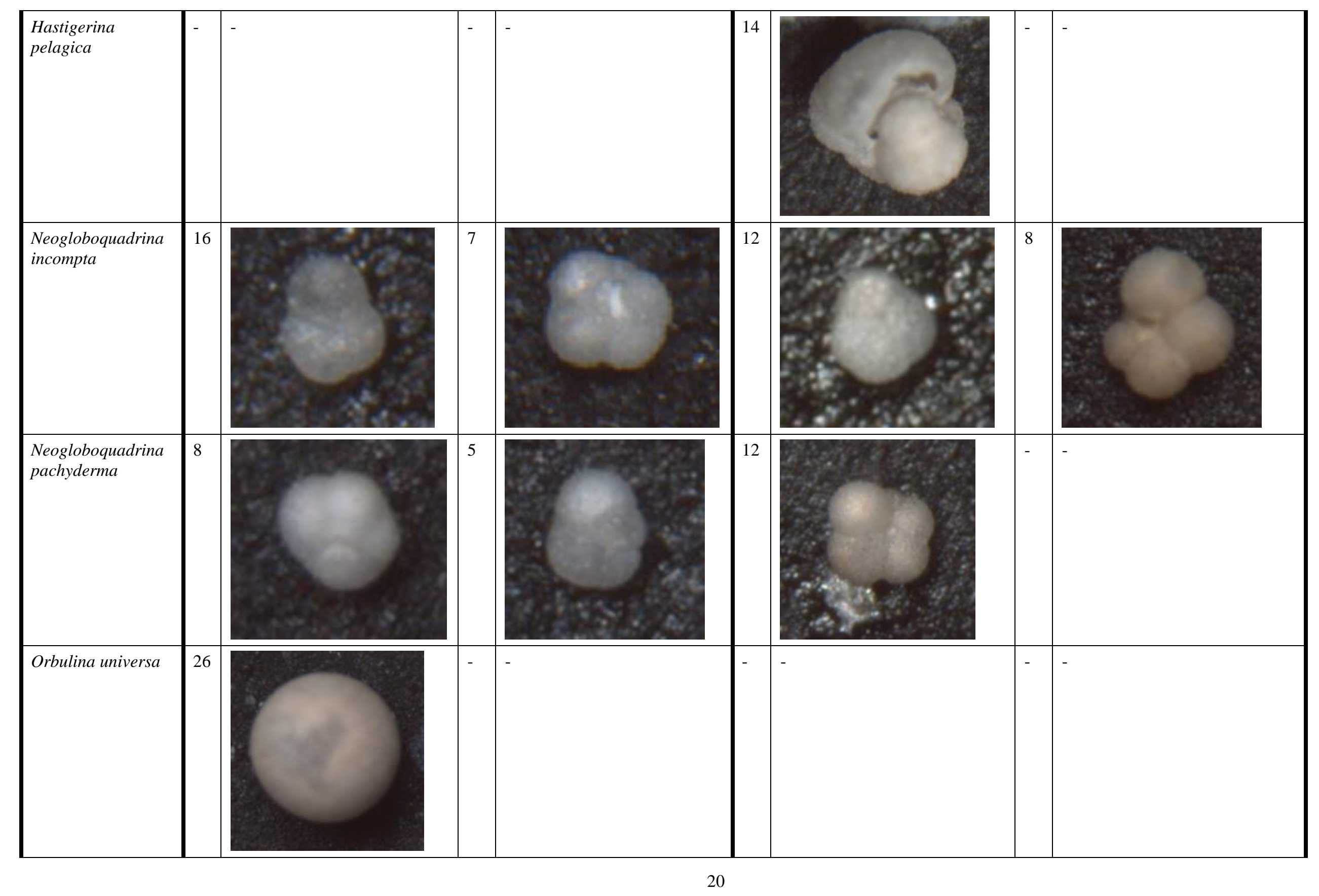




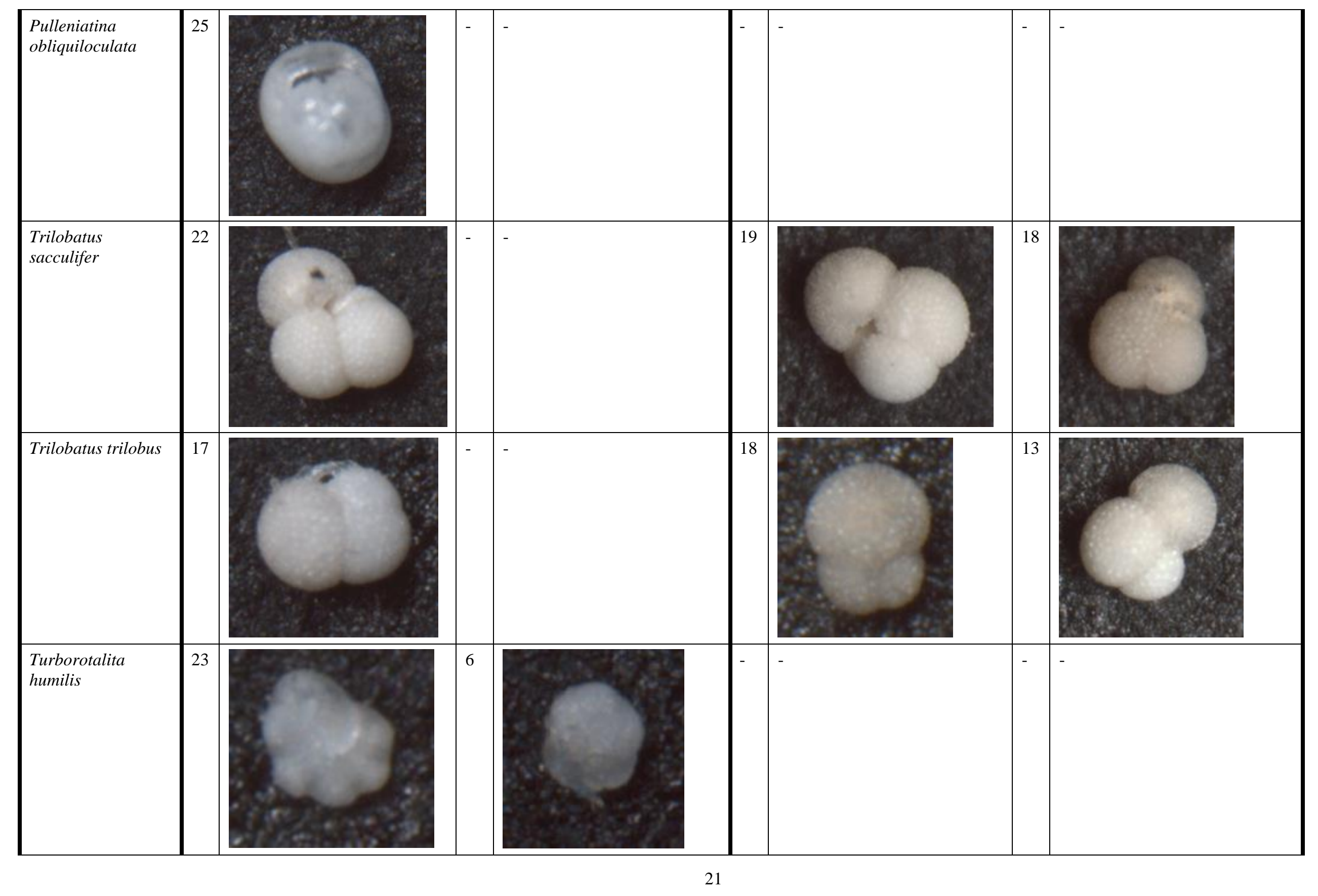




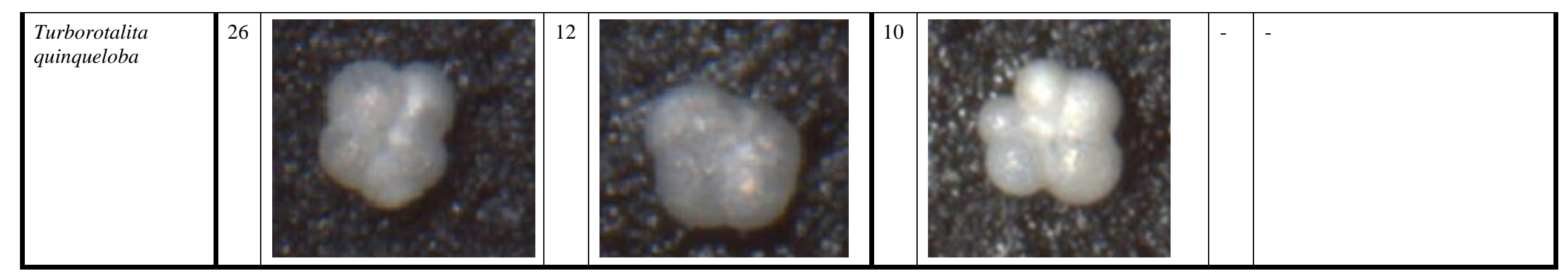

